NBER WORKING PAPER SERIES

\title{
THE IMPACT OF INTERNATIONAL PATENT SYSTEMS: EVIDENCE FROM ACCESSION TO THE EUROPEAN PATENT CONVENTION
}

\author{
Bronwyn Hall \\ Christian Helmers \\ Working Paper 24207 \\ http://www.nber.org/papers/w24207 \\ NATIONAL BUREAU OF ECONOMIC RESEARCH \\ 1050 Massachusetts Avenue \\ Cambridge, MA 02138 \\ January 2018
}

We gratefully acknowledge financial support from the European Patent Office (EPO) for the preparation of the first draft and comments from Steve Bond, Mike Devereux, Christian FonsRosen, Nikolaus Thumm, and Andy Toole. The views expressed here are those of the authors. They are not necessarily those of the European Patent Office. The paper was presented at the 12th Annual Intellectual Property Scholars Conference at Stanford, the 7th Annual EPIP Conference in Leuven, the JRC-IPTS in Sevilla, the 5th Annual Searle Center Research Roundtable on Patents and Technology Standards, the 7th ZEW/MaCCI Conference on the Economics of Innovation and Patenting, IPSDM in Mexico City, a seminar at Oxford Said Business School, Santa Clara University, and the EEA-ESEM 2016 in Geneva. The views expressed herein are those of the authors and do not necessarily reflect the views of the National Bureau of Economic Research.

NBER working papers are circulated for discussion and comment purposes. They have not been peer-reviewed or been subject to the review by the NBER Board of Directors that accompanies official NBER publications.

(C) 2018 by Bronwyn Hall and Christian Helmers. All rights reserved. Short sections of text, not to exceed two paragraphs, may be quoted without explicit permission provided that full credit, including $(\odot$ notice, is given to the source. 
The Impact of International Patent Systems: Evidence from Accession to the European Patent

Convention

Bronwyn Hall and Christian Helmers

NBER Working Paper No. 24207

January 2018

JEL No. F53,F55,O34

\begin{abstract}
We analyze the impact of accession to the regional patent system established by the European Patent Convention (EPC) on 14 countries that acceded between 2000 and 2008. We look at changes in patenting behavior by domestic and foreign applicants at the national patent offices and the European Patent Office (EPO). Our findings suggest a strong change in patent filing behavior among foreigners seeking patent protection in the accession states, substituting EPO patents for domestic patents immediately. However, there is little evidence that accession increased FDI by patenting foreign companies in accession countries. Moreover, there is no discernible reaction among domestic entities in terms of domestic filings, although we do find some evidence that applicants in accession states increased their propensity to file patents with the EPO post-accession. Inventor-level information suggests that the underlying inventions originate in the accession states
\end{abstract}

\author{
Bronwyn Hall \\ University of California at Berkeley \\ 123 Tamalpais Road \\ Berkeley, CA 94708 \\ and NBER \\ bhhall@nber.org \\ Christian Helmers \\ Department of Economics \\ Santa Clara University \\ Lucas Hall \\ Santa Clara, CA 95053 \\ christian.r.helmers@gmail.com
}




\section{Introduction}

There is a long-standing debate on the impact of intellectual property (IP) rights on innovation and economic development. ${ }^{3}$ One of the most controversial questions revolves around the strength of patent protection in lower- and middle-income economies. Underlying this debate is the fact that countries have the ability to individually determine important aspects of their IP rights systems. Although there are international agreements such as the Agreement on TradeRelated Aspects of Intellectual Property Rights (TRIPS) which harmonize and regulate important aspects of national IP systems, ${ }^{4}$ there is no global patent system, ${ }^{5}$ and only a few regional systems. ${ }^{6}$ This often overlooked fact means that patents are national rights and thus valid only in the jurisdiction that grants them. This in turn implies that regardless of the strength of statutory patent protection, the same invention may be patent-protected in one jurisdiction but not in another. Hence, apart from the availability and strength of patent protection, the need to file patents on the same invention in each country for which patent protection is sought is likely to affect companies' decisions about where to obtain patent protection and therefore their business decisions including $R \& D$, foreign direct investment (FDI), exporting, etc. It is also likely to affect business decisions of companies other than the patentees, especially those in lower- and middle-income economies.

The fragmented nature of patent protection also raises a number of other issues. First, there are doubtless a great deal of wasted resources when patent applications on the same invention need to be examined in several different offices, to say nothing of issues related to enforcement in different jurisdictions. To some extent this problem is mitigated by the PCT system which allows a single search for prior art by one of the designated international search offices. ${ }^{7}$ However, for developing countries the creation of a patent office and the acquisition of the expertise required to grant patents may use resources that would be better spent elsewhere. For this reason, regional offices may be a desirable and cost-effective solution for smaller and less developed countries. A second problem created by the existence of many national patent

3 There is an extensive literature on the issue, see for example Nordhaus (1969), Diwan and Rodrik (1991), Helpman (1993), Gould and Gruben (1996), and Lerner (2002).

${ }^{4}$ Although TRIPS regulates important aspects of national IP systems (for example, signatories have to grant patent protection on both product and process innovation), there remains considerable discretion (for example, signatories can define patent eligible subject matter).

5 There is the Patent Cooperation Treaty (PCT), which was signed in 1970 and is administered by the World Intellectual Property Organization (WIPO). The PCT offers only a simplified patent filing system for an applicant to obtain patent protection in several countries worldwide through a single application. However, the decision of whether the patent will be granted remains with the national or regional patent authorities. Hence, despite a single patent filing, there is still the need to prosecute the patent filing separately in each jurisdiction to obtain a patent grant. Enforcement and validity of PCT patents are also subject to national law and procedures.

6 The main regional systems are the European Patent Convention (EPC), covering about 40 European countries, the Organisation Africaine de la Propriété Intellectuelle (OAPI) for French-speaking Africa, the African Regional Intellectual Property Organization (ARIPO) for English-speaking Africa, and the Eurasian Patent Organization (EAPO) for Russia and the former Soviet republics. The EPC is by far the most important regional system.

${ }^{7}$ At the present time, these offices are those of Australia, Austria, Brazil, Canada, China, Chile, Egypt, Finland, India, Israel, Japan, the Republic of Korea, the Russian Federation, Spain, Sweden, Ukraine and the United States of America, as well as the European Patent Office and the Nordic Patent Institute. 
offices is that the same invention may result in patents of widely varying breadth, which can raise enforcement and other costs for both the patent holder and her competitors. A regional office could lead to more uniformity of coverage across jurisdictions.

In this paper, we examine empirically the response of firms and inventors to the addition of a regional patent system to their own national system, in an effort to understand how it affects both their innovative activity and their patenting strategies. We use data for a set of 14 countries that joined the European Patent Convention (EPC) during the 2000-2010 decade to explore the impact of the accession on patenting behavior by firms in those countries. ${ }^{8}$ The EPC is a regional patent system that provides uniform patent protection in all member and extension states and that co-exists with national patent systems. It offers a single route to obtaining a patent grant in all member and extension states. Accession to the EPC, therefore, offers an interesting setting to study the effect of the introduction of a regional patent system. The period that we study is particularly interesting because a number of relatively less developed transition and emerging market economies joined the EPC regional patent system which had been mainly composed of more advanced EU countries. ${ }^{9}$

Joining the EPC potentially has two main effects. First, it becomes cheaper for residents to simultaneously obtain patent protection both domestically and in the other countries signatory to the EPC. Second, it also becomes cheaper for foreigners to obtain patent protection in the country as they can obtain an EPC patent in the country instead of filing a separate patent application with the national office of the country. This implies that on the one hand, it becomes cheaper for domestic firms to obtain patent protection at home and abroad simultaneously, and on the other, it becomes cheaper for foreign firms to obtain patent protection in the country provided they obtain patent protection in another country signatory to the EPC. ${ }^{10}$ Using both aggregate and patent level data, we investigate how EPO and national office patenting by residents and non-residents of accession countries change following accession to the EPC. We also carry out some analysis that looks at the effect of EPC accession on FDI in accession countries.

Our analysis offers three main insights. First, there is little evidence for a drop in patent filings by domestic entities with the national office following accession. That is, entities in accession countries do not substitute filings at the EPO for domestic filings. That said, in nearly all accession countries, domestic entities filed very few patents with the national office before accession and accession did not change that. Second, we nevertheless see a modest increase in

8 The countries are: Bulgaria, Czech Republic, Estonia, Croatia, Hungary, Iceland, Lithuania, Latvia, Norway, Poland, Romania, Slovenia, Slovakia, and Turkey. See Table 2 and Appendix Table D-1. Note that our analysis includes both extension and accession to the EPC (for an explanation see Section 3 and Appendix A), although in the text we refer to both simply as accession as all countries eventually acceded to the EPC.

92005 GDP per capita averaged US\$33,800 in those countries that joined before 2000, whereas it averaged US $\$ 18,600$ (US $\$ 14,400$ excluding Iceland and Norway) in those 14 countries that joined between 2000 and 2008. See Table D-1 in the appendix.

10 In addition, a substantial share of the work burden associated with the filing and examination of patents is shifted from national offices to the European Patent Office (EPO), which may have implications for patent prosecution, such as examination practices, the speed of examination and hence backlogs. This may also have implications for national patent office budgets, due to the change in both fee levels and their allocation between national offices and the EPO -- although this is an aspect of accession that we do not investigate here. 
EPO filings by domestic entities albeit from a very low level. Analysis at the inventor-level suggests that invention does increase slightly in the accession countries. We also find some evidence for an increase in the complexity of the patent landscape in accession countries due to the (unexpected) combined use of the national and EPC systems for the same patents. Third, foreign entities react strongly to accession to the EPO. Filings with national offices by foreign entities drop by over $90 \%$ immediately following accession to the EPC as they opt for filings at the EPO instead of the domestic patent office. Despite the clear impact on patent filings, using firm-level data on FDI, we find only very weak evidence that non-residents changed their investment in accession countries following accession to the EPC.

Our analysis contributes to the literature by providing evidence on the effect of the national character of patents as well as the introduction of a regional patent system. Because most accession states were lower- and middle-middle income economies, our results also provide some insight into the impact of such international patent systems on developing countries in the rest of the world.

From a policy point of view, our analysis may in particular provide lessons for developing countries that consider joining the Patent Cooperation Treaty (PCT) system or other supranational systems. ${ }^{11}$ By facilitating the filing of patents in several jurisdictions, joining the PCT system generates similar effects to joining the EPC system. Our analysis may also inform us about the potential impact of the European patent with unitary effect in 25 countries (that are part of the enhanced cooperation agreement) which will become available in $2018 .{ }^{12}$ Under the agreement, validation of the European unitary patent in a national office is no longer required for the patent to enter into force. Our results suggest that this will lead to a sudden and persistent increase in the number of valid European patents in countries that so far recorded few validations of EPO patents. Further, the co-existence of the existing national and EPO systems with the new unitary patent during a transitional period of at least seven years may result in a substantial number of duplicate patent filings across the different systems. This will increase the complexity of the European patent landscape even further. Overall, given the expected costs savings in obtaining patent protection across several European countries due to the unitary patent, the effect may materialize in a similar way as what occurred after accession to the EPC.

The remainder of this paper is organized as follows. Section 2 reviews the existing literature on the impact of patent strength and harmonization of patent systems on countries' innovative activity and patenting. Section 3 discusses the changes in patent filing behavior brought about by accession to the EPC. Section 4 describes the data used in our analysis. Section 5 contains our analysis of patent filings. Section 6 presents results from applicant- and inventor-level analyses. Section 7 uses matched firm-level data to analyze any impact on FDI in accession countries. Section 8 concludes.

\footnotetext{
11 While the PCT system unifies at an international level the filing of patents and the provision of search reports, the examination of patents is still done by the designated national offices. In this sense, the EPC system provides a much more harmonized patent system that comes a lot closer to an international patent system than the PCT.

12 The regulations of the unitary patent were created in December 2012. For more details see http://www.epo.org/law-practice/unitary/unitary-patent.html
} 


\section{Literature}

Bilir et al. (2011) look directly at the impact of the internationalization of the patent system by joining the Paris Convention. ${ }^{13}$ They study the response of patent filings by foreign nationals to the U.S. accession to the Paris Convention in 1887. Using a sample of patents filed with the U.S. Patent and Trademark Office (USPTO) between 1865 and 1914, the authors find a strong positive impact following the accession of the U.S. on patent filings by inventors from countries that were already members of the Paris Convention prior to the U.S. relative to inventors from countries that joined later. The positive effect is more pronounced for countries with high pretreaty levels of GDP per capita and education (measured as primary schooling), suggesting that countries with higher levels of economic development respond more strongly to the international strengthening and harmonization of patent rights.

McCalman (2001) models the impact of the harmonization of intellectual property systems induced by TRIPS at the aggregate country level. He projects that there will be substantial income transfers resulting from harmonization, mostly from developing to developed countries. However, the analysis disregards the role played by multinationals and international trade in patented inventions. It is specifically this aspect that Branstetter et al. (2006) examine to find that a strengthening of IP protection in 16 countries during the period 1982-1999 had a positive impact on technology transfer within U.S. multinationals. Technology transfer is measured by the amount of royalty payments made by the U.S.-based company to its affiliates abroad for the use or sale of intangible assets. Controlling for tax differences across jurisdictions, they find that affiliates' R\&D expenditure and patent applications increased, with a stronger effect for affiliate firms that have highly patent-active parent companies in the U.S.

The analysis by Branstetter et al. (2006) is part of a broader, related literature that analyzes the impact of patent strength on innovation. Most of the empirical studies in this literature rely on aggregate country-level data to explore correlations between some measure of the strength of IP rights protection, economic growth and innovation. For example, Gould and Gruben (1996) use a standard growth model to find a positive association between an index of patent protection and growth of GDP at the country level (for 1960-1988). Instrumental variable estimation suggests that the relationship is causal rather than simultaneous. Kanwar and Evenson (2003) look more directly at the relationship between IP protection and innovation. They find a strong positive correlation between the strength of patent protection and innovation measured as R\&D intensity for a sample of 29 countries over the period 1981-1990. Similar evidence supporting a positive relationship between IP protection and innovation is provided by Chen and Puttitanum (2005) for a sample of 64 developing countries (1975-2000) measuring innovation as patenting. However, Qian (2007) uses data on 26 countries and matched sampling methods to look closely at the impact of national patent protection on pharmaceutical innovation and finds little impact, unless the country adopting a patent system is already at a higher level of development.

\footnotetext{
13 The Paris Convention harmonizes national patent systems by providing national treatment and the socalled priority right. In particular the priority right facilitates the filing of patents in different jurisdictions as it allows applicants to preserve the first filing date in any of the signatory states as the patent's priority date within 12 months from the first filing.
} 
A key problem in some, but not all, of these analyses is the endogeneity inherent in a country's strength of patent protection; countries with superior innovative performance are more likely to choose strong patent protection. ${ }^{14}$ Sakakibara and Branstetter (2001) address this problem by exploiting an exogenous change in the patent law in Japan in 1988, which extended the scope of patents mainly by allowing applicants to include several independent claims in a single patent specification. Their firm-level analysis shows no discernible impact of stronger patent rights on firms' R\&D investment or patenting. Similarly, Scherer and Weisburst (1995) exploit a change in patent law in Italy in 1982 that allowed patentability of pharmaceutical compounds. The authors treat the law change as exogenous because it was mandated by the Italian Supreme Court rather than the direct outcome of lobbying by pharmaceutical companies. Their analysis, which is based only on aggregate industry-level data, suggests no statistically significant impact on R\&D spending although there was an increase in patenting by domestic companies in the U.S. following the law change. The authors interpret this as indicative of a change in patenting propensity, i.e., firms patented more for a given amount of R\&D investment. ${ }^{15}$

This short review of the existing literature shows that the evidence on the effect of internationalization of the patent system is very limited. The only existing studies focus on relatively broad international agreements that only affected certain aspects of national patent systems but which did not produce a system that allowed obtaining a patent grant simultaneously in multiple jurisdictions. ${ }^{16}$

\section{The impact of accession to the EPC}

As of March 2016, there are 38 EPC contracting states. Before acceding to the EPC, countries can sign an extension agreement with the EPO which extends the possibility of patent protection for patents granted by the EPO to countries that are not members of the EPC. Extension states usually accede eventually to the EPC, although the majority of member states have acceded to the EPC without prior extension agreements, as is shown in Table 2 later in Section 4.

The key feature of the EPC is the harmonization and standardization of the granting procedure of patents in all member and extension states. Patent applications are filed with a single office, the EPO, which examines and grants the patent. Nevertheless, patentees are required to extend (in the case of extension states) or validate (in the case of EPC member states) the granted patent in each national office of each country in which the patent should be enforceable. Extension/validation in a national office requires prior designation during the grant process. Once granted, it requires the payment of extension/validation fees as well as translation costs,

\footnotetext{
${ }^{14}$ For example, Ginarte and Park (1997) find that countries characterized by higher R\&D levels, market freedom, and openness tend to have stronger patent protection. Moreover, the results suggest that there is a critical size of a country's R\&D activity that drives countries to adopt stronger patent protection. Lerner (2002) looks at changes in the presence and strength of patent protection in 60 countries over a period of 150 years (1850-1999) to find a country's GDP to be positively correlated with having a patent system in place. He also finds civil law as well as democratic countries to be more likely to have a (stronger) patent system.

15 See also Moser (2005) and Lerner (2002) for evidence based on 19 ${ }^{\text {th }}$ century patenting.

${ }^{16}$ However, there is some recent work on the trademark system. Herz and Mejer (2016) study the effect of the introduction of the European Union (EU) Trademark in 1996 which created the possibility to obtain trademark protection throughout the EU with a single trademark filing.
} 
although exceptions apply for contracting states to the London Agreement. ${ }^{17}$ The national character of granted patents implies that they have to be kept in force in each individual country by paying renewal fees. Hence, turning an EPO patent into nationally enforceable rights requires:

a. all the costs associated with the grant of an EPO patent (application fee, European search fee, examination fee, grant fee, and EPO renewal fees beginning the $3^{\text {rd }}$ year from the date of filing until the patent is granted by the EPO);

b. the specific costs incurred for obtaining national patent rights (designation fee, translation fees, and validation fees).

These account for the main difference between obtaining a patent right in a given member/extension state of the EPC through the EPO or directly with the national office. An additional difference arises from potential cost differences between employing the services of a European patent attorney and a national/local patent attorney.

To obtain an EPO patent, fees payable to the EPO beginning the third year counting from the application date until grant of a European patent that designates two EPC countries amount to about EUR 4,360.18 To file with the EPO, domestic applicants in our set of accession states also need to translate their patent specification into one of the three official languages of the EPO, which is likely to be costly. ${ }^{19}$

Before 1 April 2009, which is the relevant period for our analysis, designation fees per designated country amounted to EUR 90 and are capped at EUR 630, i.e., there is no additional cost to designating more than seven countries. Extension and validation fees at national offices vary across offices. While for example Norway and Slovenia do not charge validation fees, they amount to nearly EUR 170 in Turkey. Appendix Table D-2 summarizes the different applicable validation fees. Apart from designation, extension and validation fees, to obtain patent protection nationally, applicants may also incur additional expenses due to translation requirements.

In contrast, obtaining a patent directly with a national office is considerably cheaper than the EPO route. Similar to validation fees, the costs differ considerably across national patent offices. For example, national fees amount to approximately EUR 220 in Lithuania and to over EUR 900 in Norway.

While national renewal fees are incurred irrespective of the route taken, Harhoff et al. (2009) suggest that their level still impacts on a patentee's choice of whether to validate a given EPO patent in a designated state. This means that the level of renewal fees may still impact on the choice of countries in which a patent is obtained, whether it is through the national office or the

${ }^{17}$ In the countries signatory to the London Agreement, foreign applicants only need a translation of the claims of their EPO patent into the local language in order to validate the patent in the country. Among our set of countries, translation of the complete patent specification is still required by Bulgaria, the Czech Republic, Estonia, Norway, Poland, Romania, Slovakia, and Turkey.

18 As of April 2010 (EPO Supplement 1 to Official Journal 3, 2010), the total cost can be computed as follows: application fee EUR 105 (filed online); European search fee EUR 1,105; examination fee EUR 1,480; grant fee EUR 830; renewal fees for $3^{\text {rd }}$ and $4^{\text {th }}$ year from the date of filing: EUR 420 and EUR 525.

${ }^{19}$ Practitioner estimates of translation costs are EUR 75-85 per page with an estimated average of 23 pages per patent specification (Roland Berger, 2004). 
EPO route. Nevertheless, for a specific country the renewal fees are irrelevant for the choice between filing with the national office and the EPO since the same fees incur in both cases. The same applies to translation fees provided the national office requires translation of the entire patent upon validation.

Table 1 summarizes the different choices that resident and non-resident patentees can make. Before accession the choice is between filing a national patent and filing an EPO patent abroad or doing both. Post-accession, the choice set grows. Now applicants have the additional option of obtaining an EPO patent in the accession country instead of a national filing.

Table 1: Impact of accession to the EPC

\begin{tabular}{|c|c|c|c|c|c|}
\hline \multicolumn{3}{|c|}{ Before accession } & \multicolumn{3}{|c|}{ After accession } \\
\hline \multirow[t]{2}{*}{ National } & \multicolumn{2}{|c|}{ EPO } & \multirow[t]{2}{*}{ National } & \multicolumn{2}{|c|}{ EPO } \\
\hline & Home & Abroad & & Home & Abroad \\
\hline Yes & & Yes & Yes & No* & Yes \\
\hline \multirow[t]{2}{*}{ No } & & Yes & No & No & Yes \\
\hline & & & No & Yes & Yes \\
\hline Yes & & No & Yes & No & No \\
\hline No & & No & No & No & No \\
\hline
\end{tabular}

The table describes the choices available to a given applicant before and after extension/accession. For example, before accession, a given applicant has the option to file for a national patent with the national patent office and to obtain patent protection abroad by filing an EPO patent and validating it abroad.

* Post accession, national filings and filings with the EPO are substitutes which means in principle we should not observe such duplicate filings; however, in practice, we see such filings in the data (see Section 5.2 below).

In our empirical analysis, we are interested in estimating the impact of accession on the patenting behavior of both domestic and foreign inventors. The discussion above suggests that any effect of accession to the EPC should come mainly from a shift in the costs (including costs associated with the difficulty of having to file in a foreign country) associated with obtaining a patent in a given country. Appendix B offers a simple model that analyzes the impact of accession slightly more formally.

\section{Data}

We analyze the impact of accession to the EPC for the 14 contracting states that acceded to the EPC between 2002 and 2008. The list is shown below in Table 2, where European Union (EU) members are shaded in grey (see also appendix Table D-1). ${ }^{20}$

${ }^{20}$ Due to a lack of sufficient data, the following contracting states are excluded from the analysis: Albania, Former Yugoslav Republic of Macedonia, Serbia, Malta, Montenegro, and San Marino. 
Table 2: Accession states and dates

\begin{tabular}{lcccrr}
\hline Country & $\begin{array}{c}\text { EPC Extension } \\
\text { Date }\end{array}$ & $\begin{array}{c}\text { EPC Accession } \\
\text { Date }\end{array}$ & $\begin{array}{c}\text { EU Accession } \\
\text { Year }\end{array}$ & $\begin{array}{r}\text { GDP in } \\
\text { 2005* }\end{array}$ & $\begin{array}{r}\text { GDP per } \\
\text { capita }\end{array}$ \\
\hline Bulgaria & & 1-Jul-2002 & 2007 & 74,896 & 9,678 \\
Croatia & 1-Apr-2004 & 1-Jan-2008 & 2013 & 63,820 & 14,367 \\
Czech Republic & & 1-Jul-2002 & 2004 & 208,287 & 20,379 \\
Estonia & & 1-Jul-2002 & 2004 & 20,658 & 15,349 \\
Hungary & & 1-Jan-2003 & 2004 & 161,505 & 16,011 \\
Iceland & & 1-Nov-2004 & & 9,404 & 31,690 \\
Latvia & 1-May-1995 & 1-Jul-2005 & 2004 & 28,311 & 12,280 \\
Lithuania & 5-Jul-1994 & 1-Dec-2004 & 2004 & 46,682 & 13,667 \\
Norway & & 1-Jan-2008 & & 287,147 & 62,109 \\
Poland & & 1-Mar-2004 & 2004 & 511,949 & 13,414 \\
Romania & 15-Oct-1996 & 1-Mar-2003 & 2007 & 200,192 & 9,195 \\
Slovakia & & 1-Jul-2002 & 2004 & 82,222 & 15,183 \\
Slovenia & 1-Mar-1994 & 1-Dec-2002 & 2004 & 44,191 & 22,073 \\
Turkey & & 1-Nov-2000 & & 755,490 & 11,087 \\
\hline
\end{tabular}

*Output-based GDP in 2005 US dollars, at PPP.

Source: Penn World Tables, Version 8.1

Note: grey shaded areas indicate country is European Union (EU) member

The set of countries covered by our analysis is heterogeneous. It includes a large number of former Eastern bloc countries, the Scandinavian countries Iceland and Norway, as well as the large transition economy Turkey. As noted earlier, these countries generally have lower GDP per capita than the EPC founding states, with the exception of Iceland and Norway.

All accession states that also became part of the EU joined the EPC before officially becoming a member of the EU (with the exception of Latvia, which acceded six months after joining the EU). The fact that all members of the EU have to be signatories of the EPC (but not vice versa) mitigates concerns of any endogeneity in the decision to join the EPC. The decision to join the EPC was taken by these countries within the broader context of acceding the EU. They generally did not attribute any specific importance to accession to the EPC especially within the context of other common and much broader regulatory challenges presented by accession to the EU. ${ }^{21}$ To test this more formally, in appendix Table D-3 we show the results of a hazard rate regression for accession as a function of the country's population, GDP, and past domestic patenting. Although the power of this test is low due to the small sample size, none of these variables has any predictive power for accession, nor are they jointly significant.

The patent data for the analysis presented below come from EPO's Patstat database (version October 2015). We extracted patents filed with national patent offices, at the EPO and via the PCT route at the World Intellectual Property Organization (WIPO). Our analysis focuses on

21 We also confirmed this in conversations with representatives from various patent offices in accession countries. 
patents filed by residents of the countries listed above and residents of other countries (referred to as "non-residents" in the analysis) with the national office as well as the EPO (and WIPO). Appendix A explains in detail how we identify EPO patents that have been validated in an accession state.

The patent data we use include filings at all offices between 1995 and 2014, although for some of the analysis we restrict the period considered to that 3 years (12 quarters) before and after the accession date for each country.

The firm-level data used in the analysis of foreign ownership of companies in accession countries presented in Section 7 come from Bureau van Dijk's Amadeus database. We use the Amadeus data to determine whether any non-resident patentees change their direct investment behavior in accession countries following accession to the EPC. To do this, we use the detailed information on corporate ownership structure provided by Amadeus. The information allows us to construct international business groups and hence to determine any foreign ownership of companies in accession countries (see appendix Table D-4). We use annual versions of the data covering the period 2000-2011,22 which means we are able to track changes in ownership over time. The data nevertheless have important limitations for our analysis which are discussed in detail in Section 7.

In order to combine the Amadeus with the patent data, we proceeded as follows: we first identify all foreign companies with an ownership stake in any company registered in an accession country over the period 2000-2011. We then match the set of 45,872 foreign parent companies to the patent data. The data are matched by applicant name due to the absence of a unique identifier that would allow merging the datasets. We matched company and applicant names using a combination of automated matching and manual matching to minimize the occurrence of "false positives", i.e. firms are erroneously matched to patents, and "false negatives", firms are erroneously not matched to their patents. We match 9,162 parent companies to the set of non-resident patentees, i.e., around 20 per cent.

In the next sections of the paper we use these data to analyze aggregate patent filings by residents and non-residents, applicant-level and inventor-level filings, and changes in FDI, all as a function of the date a country acceded to the EPC.

\section{Aggregate analysis}

\subsection{National office filings}

We first show that there have been large changes in aggregate patent filings following accession to the EPC. In Figure 1, we compare filings by residents and non-residents with the national offices around the time of accession. ${ }^{23}$ The figure shows a dramatic effect of accession to the EPC

22 Using annual versions of Amadeus is necessary in order to avoid sample attrition as Bureau van Dijk drops inactive firms after four years, which means we would potentially miss firms that were active in the early 2000s, but went out of business by 2007, if we were to use only a single version of Amadeus.

${ }^{23}$ We have complete patent data for at least 12 quarters post-accession for all countries. This ensures that changes in the number of patent filings are not driven by entry and exit of countries into the sample. In order to visualize any potential changes following accession, in much of what follows we rescale the time 
on filings by non-resident applicants at the national offices. Non-residents' filings drop between the pre-accession and post-accession quarters by over $90 \%$ from about 6,000 to fewer than 500 applications. More surprisingly, resident filings, in contrast, seem to be largely unaffected. A potential implication is that joining the EPC had no immediate benefit for the residents of the accession countries.

\section{Figure 1: Patent filings at national office by non-residents and residents (by quarter)}

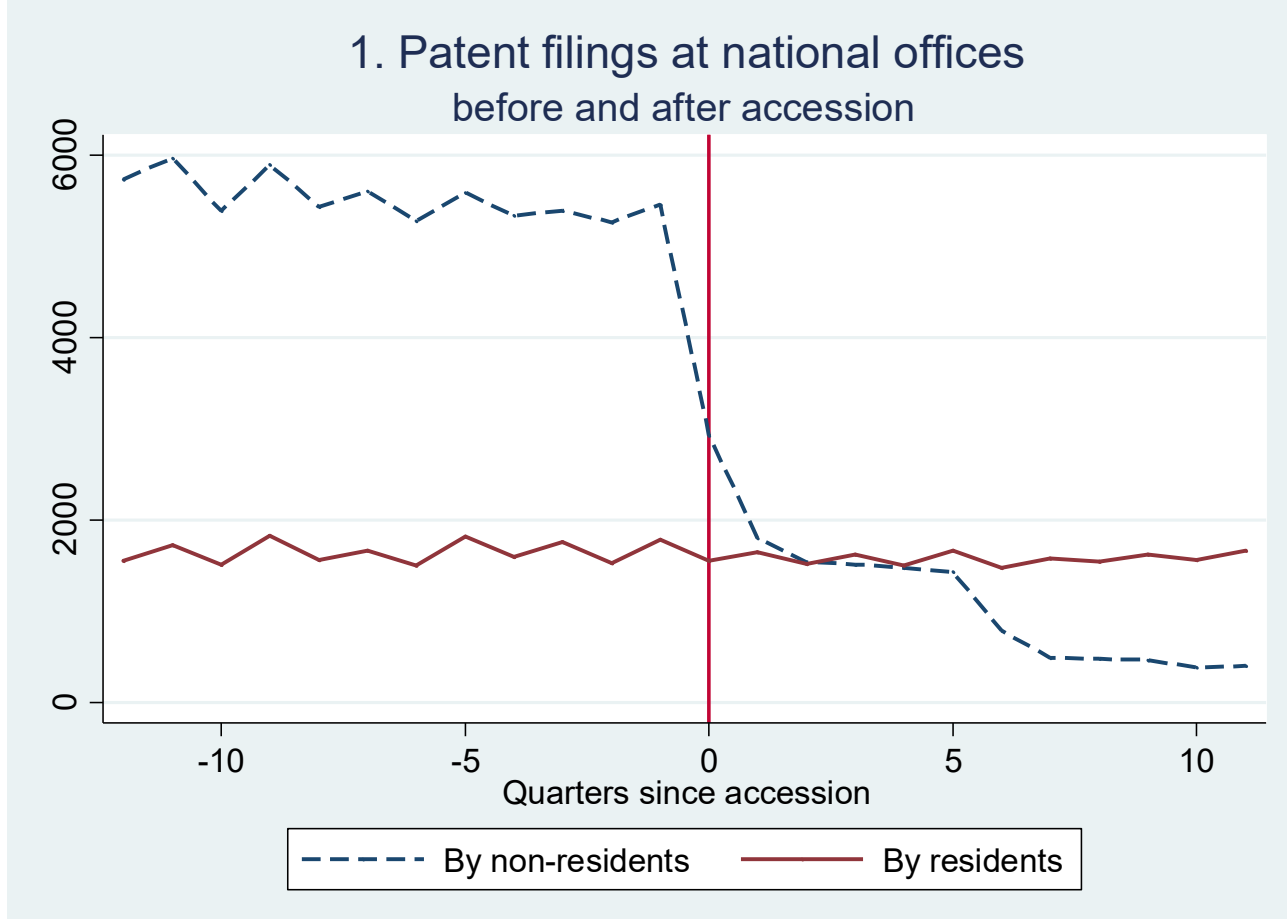

Note: time represents the application date of a patent. Number of patent filings by country have been corrected for equivalents.

In Figures $2 \mathrm{a}$ and $2 \mathrm{~b}$ we examine the variation in accession country response to joining the EPC (see also appendix Table D-5). For visibility on the graphs, we divide the countries into two groups, those that average more than 100 filings per quarter and those with fewer. Only 5 countries are in the larger group: the Czech Republic, Hungary, Norway, Poland, and Slovakia. All of these except Norway show the same pattern in the aggregate figure. The anomalous result of a second decline in non-resident patenting in Figure 1 turns out to be due almost entirely to Norway, with a small contribution from Iceland. This delayed response may be due to fact that the EPO filing date for a PCT application is the PCT filing date, rather than the actual EPO date,

period for all countries (the quarter of the accession date is time zero). The regressions presented later in the paper control for the fact that there are also underlying trends in patent applications using calendar quarter-year dummies. 
which means that PCT applications during 2008 would not be available for Norwegian designation, even if they were filed at the EPO after January 2008.24

Looking at the countries with fewer than 100 filings per quarter, Estonia and Turkey show a similar pattern as the larger countries, while Croatia shows a decline occurring about 10 quarters before the accession date of January 2008. This is most likely due to the fact that Croatia became an extension state earlier in April 2004. As described earlier, this status allows applicants to extend their EPO applications to the country and to validate them there as national patents if they are granted at the EPO. The other countries with extension status prior to becoming full members of the EPC (Latvia, Lithuania, Romania, Slovenia) have so few patent filings by non-residents throughout the period that we see little response either to extension or accession.

Figure 2a: Patent filings at national office by non-residents and residents (larger countries)

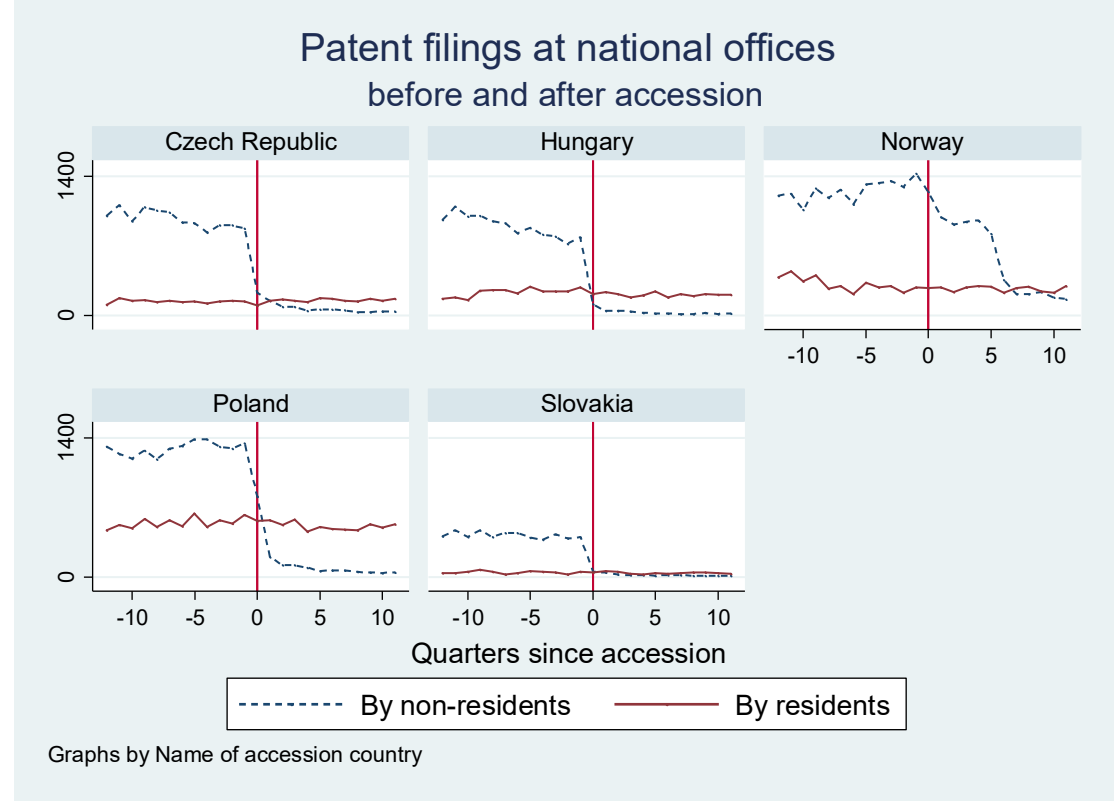

Note: time represents the application date of a patent.

${ }^{24}$ See http://ipkitten.blogspot.com/2009/02/plea-from-norway.html for a discussion of this issue. Also http://ip-updates.blogspot.com/2007/11/norway-joins-epc-on-january-1-2008.html for the EPO rules. 


\section{Figure 2b: Patent filings at national office by non-residents and residents (smaller countries)}

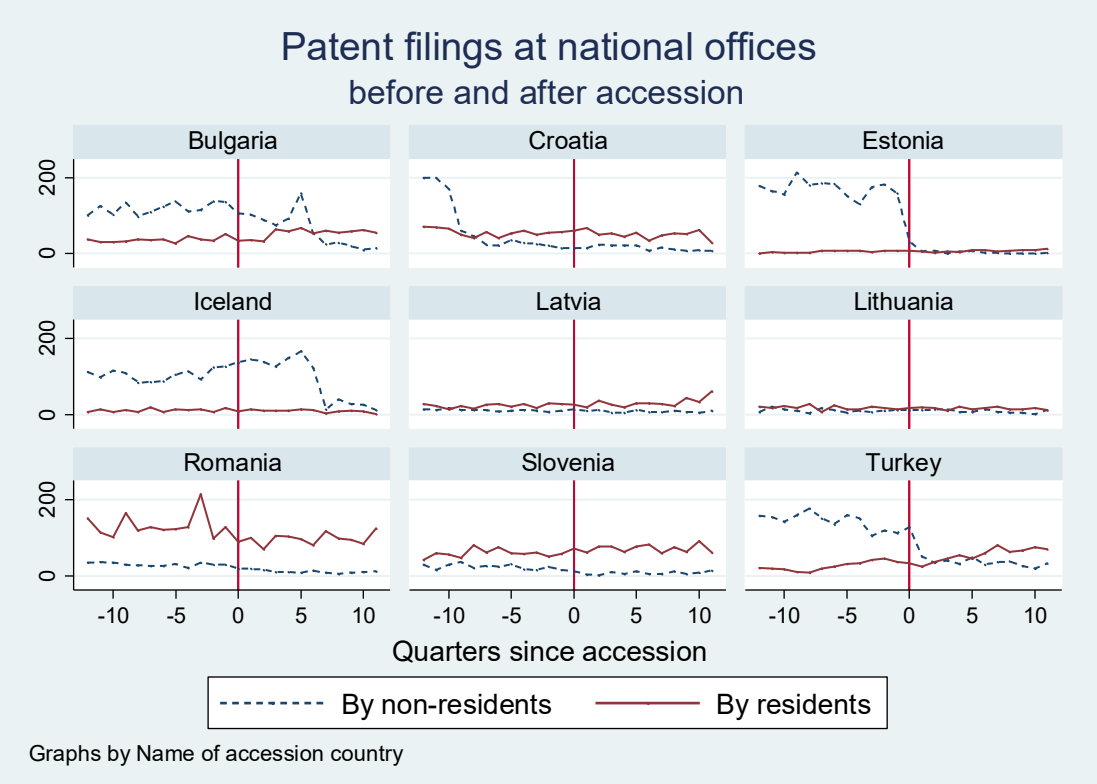

$\underline{\text { Note: }}$ time represents the application date of a patent.

This first look at the impact of accession to the EPC reveals two basic facts: 1) Before accession there is relatively little patenting by residents of accession countries with the exception of Poland and Norway. 2) After accession, non-residents almost immediately stop applying for patents at the national offices. The only perhaps surprising result is that the residents of these countries who do patent are largely unaffected by accession to the EPO.

\subsection{EPO filings}

The discussion in Section 3 above and the model in appendix B suggest that the non-response of residents to EPC accession could be because they only wish to patent in one or two countries, and there is no cost advantage from switching to an EPO patent filing. We examined this hypothesis by looking at the distribution of patent family filings (equivalents for the same invention, defined as patent applications that share a priority patent) ${ }^{25}$ across the three choices: (a) EPO only, (b) national office only and (c) both the EPO and the national office. This distribution is shown in Figure 3, by quarters before and after accession to the EPC. There is a complication due to the fact that patent filings at the EPO and the national office usually take place 3 to 4 quarters apart. The figure shown is based on priority date, where each unique

25 As explained in the Introduction, separate patent applications have to be filed in each jurisdiction in which patent protection is sought. Since these separate patent filings are based on the same invention, they form a so-called patent family. To facilitate obtaining patent protection in multiple jurisdictions, the Paris Convention allows "family members" (also referred to as equivalents) to be filed within 12 months of the first filing in any jurisdiction signatory to the convention while preserving the first filing date (e.g. if a patent is filed first in Germany on January $1^{\text {st }} 2000$, and then the patent is filed in the U.S., say on October $1^{\text {st }} 2000$, the U.S. patent office will treat the patent as if it had been filed on January $1^{\text {st }} 2000$ ). This first filing date is referred to as the priority date and the corresponding patent as the priority patent. 
priority is counted only once, and the dating is relative to the priority date. Figure D-1 in the appendix shows a version of the figure based on the application date, where each filing that occurs both at the EPO and the national office is counted twice (hence the relatively large size of the central band). Both figures show a similar pattern: first, the vast majority of patent filings by residents of accession countries are at their national offices and this remains true after accession. Second, there is a doubling of EPO filings after accession, but from a very small base (from about 50 per quarter to 100 per quarter). Finally, and somewhat puzzling, the share of patents filed at both the EPO and the relevant national office is largely unchanged by accession, in spite of the fact that this strategy would appear to be more expensive than simply filing at the EPO and designating one's own country among others.

\section{Figure 3: Patent filings by residents of accession countries by quarter before and after accession}

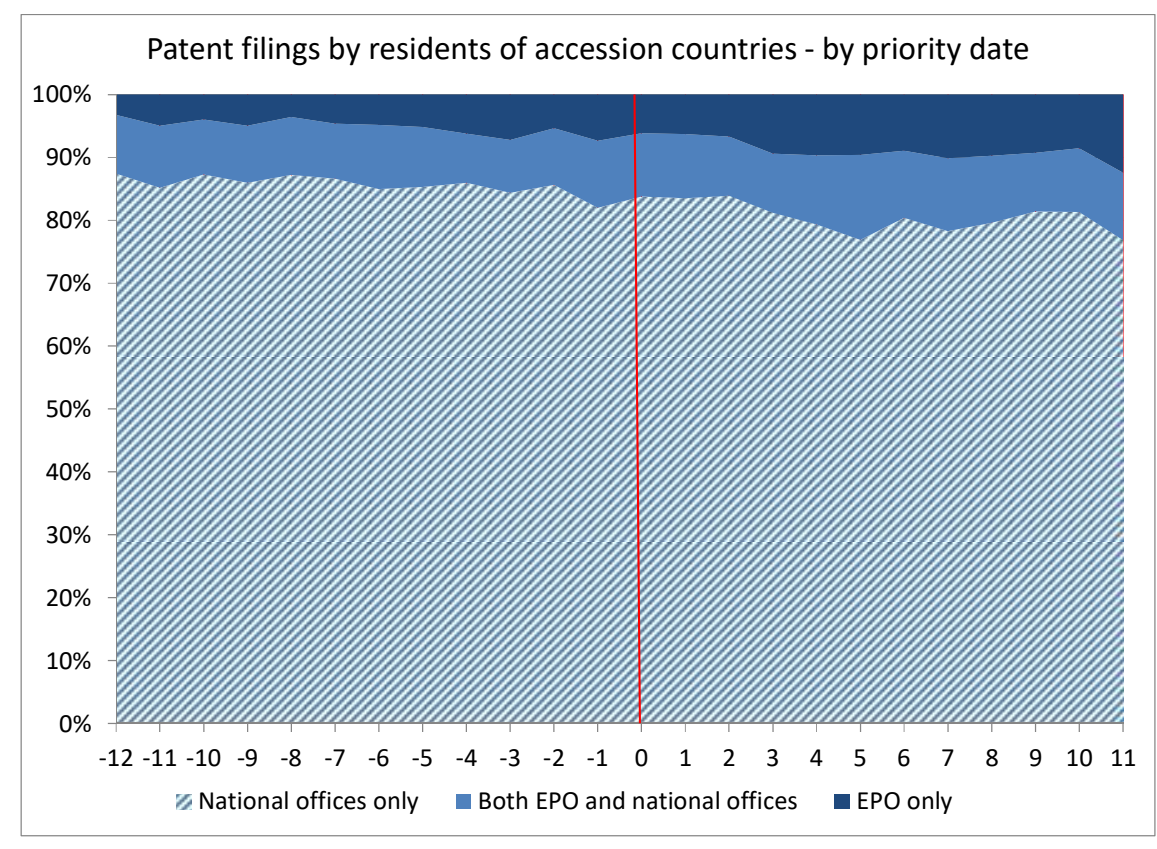

At the time of filing, applicants to the EPO can designate the member states for which they desire patent coverage, paying a nominal fee (90 euros) for each, up to a maximum of 7 , after which the subsequent states are free. In practice, the majority of EPO applicants designate all or almost all of the member states. However, after grant they can choose whether or not to validate the patent in these member states, and in practice, applicants validate in fewer countries than they have designated (Harhoff et al. 2009).

Unfortunately, determining precisely whether a granted EPO patent has been validated in the accession countries proves to be somewhat difficult, due to lags in reporting from the national offices to the various databases from which the Patstat legal status table draws information, as well as apparently missing data in some cases. Appendix A presents data from Patstat and discusses this issue more completely. As in Harhoff et al. (2012), we define validation as the recording of fee payment to the national office, lapsing at the national office more than one year after grant, or withdrawal or expiration at the national office. 
Table 3 investigates the grant and validation behavior for accession country resident filings to the EPO and finds that they behave like other EPO applicants and that this behavior is not changed very much by accession to the EPO. Both before and after, about 80 per cent of the applications from applicants who use both national offices and the EPO validate in more than 6 states. The number of validations is slightly higher for applicants that use only the EPO, but not by much. The median number of validated states for those using both offices does not increase after accession, whereas the median number for those using the EPO only increases from 12 to 13.

Table 3

\begin{tabular}{|c|c|c|c|c|}
\hline \multirow{2}{*}{$\begin{array}{l}\text { Number of } \\
\text { validated states } \\
\text { at EPO }\end{array}$} & \multicolumn{2}{|c|}{$\begin{array}{c}\text { Applicant at EPO and } \\
\text { national office }\end{array}$} & \multicolumn{2}{|c|}{ Applicant at EPO only } \\
\hline & $\begin{array}{r}\text { Before } \\
\text { accession }\end{array}$ & $\begin{array}{r}\text { After } \\
\text { accession }\end{array}$ & $\begin{array}{r}\text { Before } \\
\text { accession }\end{array}$ & $\begin{array}{r}\text { After } \\
\text { accession }\end{array}$ \\
\hline Zero & $0.3 \%$ & $0.0 \%$ & $1.2 \%$ & $0.0 \%$ \\
\hline $1-3$ & $7.0 \%$ & $8.6 \%$ & $7.7 \%$ & $6.7 \%$ \\
\hline $4-6$ & $10.8 \%$ & $11.2 \%$ & $8.9 \%$ & $9.9 \%$ \\
\hline More than 6 & $81.9 \%$ & $80.2 \%$ & $82.2 \%$ & $83.4 \%$ \\
\hline Total filings & 722 & 723 & 244 & 433 \\
\hline
\end{tabular}

Before is defined as 12 quarters prior to the accession date and after as the accession quarter plus the 11 quarters following.

Unit of observation is an EP patent application by an accession country resident.

The fact that accession country residents hardly change their filing strategies after accession is puzzling, because it would presumably become much cheaper to simply validate an EPO patent in their own country. Clearly they are validating in a large number of states (including their own) so it would be feasible at low cost. There are several possible explanations for this fact:

1. The applicant may wish to obtain a search report cheaply from his national office before pursuing an international application. ${ }^{26}$ In this case, we would not expect to see a grant of the patent, as the applicant is likely to withdraw the application before grant. ${ }^{27}$

2. The applicant could have different expectations of granting probability, and seek to maximize the chance that he receives at least one patent grant.

3. The applicant may wish to create the maximum amount of uncertainty about the extent of his intellectual property rights for his competitors.

4. The actual claims on the applications may differ, in spite of the fact that the applications claim the same priority patent application.

\footnotetext{
${ }^{26}$ Search reports are issued by patent examiners during the examination process and provide an evaluation of the patentability of the invention submitted for examination.
}

27 We are grateful to Roger Burt for suggesting this possibility. 
Explanation (1) is somewhat difficult to assess because of grant lags. But there is some support for it if we restrict analysis to accession countries prior to 2008 (excluding Norway and Croatia). During the 12 quarters prior to accession, about 80 percent of the patents with equivalents at both offices were granted before 2013, whereas after accession, only 47 per cent were granted during the first 12 quarters following. We also examined the cases where an accession country resident applied for a patent on the same invention at both the national office and the EPO after accession. In almost all cases, the priority patent was the national office patent, as suggested by (1) above. However, in about a quarter of the cases where we observed either a grant at the national office or a validation in the accession country after an EPO grant or both, the patent did appear to be pursued until grant and validation at both offices. The median lag between the national grant and the subsequent EPO grant is about 2 years, and a significant number have a lag longer than 5 years. Because the national patent lapses if an equivalent EPO patent is validated in the country, this suggests that one reason for the dual approach may be the earlier coverage that is obtained via a national patent filing.

The conclusion is that the co-existence of national and EPO patents in a given jurisdiction postaccession allows on the one hand for duplicate patent filings and on the other hand allows applicants to combine the benefits of both systems (speed vs. coverage). Regardless of the reasons behind these findings, the effect of the co-existence of the national and EPC systems is to increase the complexity of the patent landscape faced by other firms and individuals, especially in the earlier life of the invention, before an EPO patent issues.

\subsection{Regression analysis}

The results of the graphical analysis so far suggest the following two conclusions: 1) accession to the EPC has little impact on patenting by residents of the accession countries, whereas 2) non-residents immediately switch (almost) all their applications to the EPO. Next, we evaluate this result more carefully using simple regression analysis of aggregate patent applications and grants in order to isolate the impact of accession to the EPC on the patent filing behavior from confounding factors such as broader economic reforms, EU accession, and unobserved heterogeneity more broadly.

To identify the accession effect, we rely on the staggered timing of accession, i.e., we exploit the fact that countries joined the EPC at different points in time (see Table 2). Hence, an estimate of the impact of joining the regional system is obtained from comparing patent counts before and after accession in a given country relative to the change observed during the same period of time in another country that is not joining the EPC at the same time. ${ }^{28}$ The main motivation for adopting this approach is the absence of any countries that could serve as controls. For one thing, existing EPC members were directly affected by accession and hence are not a valid control. Since nearly all Eastern European countries joined the EPC, there are few potential control countries that never joined, such as Belarus or Ukraine, which arguably differ in many observable and unobservable ways from our set of accession countries.

An important assumption underlying our approach is the exogeneity of the decision to join the EPC and the timing of accession with respect to an applicant's patenting activities (see Section

28 This identification strategy is similar to Acharya et al. (2014) and Png (2017). 
3). The graphical evidence on resident and non-resident applicants' filing behavior presented above, reassuringly showed little evidence for accession to have occurred during a general upward or downward trend in patent filings prior to accession. The exogeneity of accession is mainly explained by the fact that most accession countries in our sample acceded the EPC as part of much broader (structural) changes undertaken to accede the EU. See also appendix Table D-3, which shows a proportional hazard model of accession as a function of population, GCP, and aggregate patenting in the country. These variables are jointly insignificant in predicting accession.

The estimation method used here is Poisson with the dependent variable equal to various patent counts. The coefficients of interest are a dummy post-accession and a trend (also postaccession) to allow for slow adjustment to the change in regime. Our specification includes calendar quarter-year dummies to adjust for the fact that overall patenting activity is changing during this period, as well as a full set of country dummies to control for the differential size of their economies. The sample has been restricted to the 24 quarters around the accession date, to avoid contamination with other events and trends as much as possible. Regressions for the whole time period (1995-2013) are shown in appendix Table D-6 and they are qualitatively the same, but show a few differences.

In Table 4, the top panel of the table shows application regressions and the bottom half shows grants. It is not possible to analyze non-resident applications at the EPO in a meaningful way because most of them will never be validated in an accession country and there is no single accession date around which to examine them. Therefore, two columns are empty in the top half of the table.

Looking at the applications first, we can see that the main impact of accession is a decrease in non-resident applications at the national offices. The one-time impact is a $70 \%$ decline $(=1-$ $\exp (-1.21)$ ) in applications, followed by a further decline of $17 \%$ per year (weakly significant). Resident applications also decline, but by a much smaller amount, about $10 \%$.

The results for grants are somewhat different. It should be kept in mind that national office legal status (including grant status) may be somewhat mismeasured due to reporting lags, and in the case of Slovenia and Turkey, we have no information on grants at the national office so those countries are dropped in the regressions for national office grants. The first three columns on the bottom panel pertain to patents granted to residents of accession countries. Column one is for EP grants to residents, by accession country. These may include patents that are validated only in non-accession countries as well as those validated in accession countries. The next column focuses on EP grants to residents of accession countries that are validated in their home country. Finally, the third column is for resident grants at their own national office. Comparing these numbers, we see a large increase in validation of EP patents in the home country (not surprising since prior to accession this was not possible), a somewhat smaller but growing increase in EP grants to residents of accession countries overall, and a small decline in grants at national offices to residents, one which is commensurate with the small decline in applications. Thus there is some evidence that residents of accession countries do take advantage of their access to the EPO, although at a low level, recalling the earlier figures.

For non-residents the picture is simpler: EPO grants to non-residents that are validated in accession countries increase by the same percentage as the decline in national office grants, 
suggesting substitution. There is also a small declining post-accession trend at the national offices for these applicants.

Table 4

Predicting aggregate patent applications

Dependent variable: patent filings in the quarter 336 obs $=14$ countries $\times 24$ quarters around accession date

\begin{tabular}{lccc}
\hline & $\begin{array}{c}\text { EPO applications } \\
\text { by residents }\end{array}$ & $\begin{array}{c}\text { Resident } \\
\text { applications at } \\
\text { national offices }\end{array}$ & $-0.10(0.03)^{* * *}$ \\
$\begin{array}{l}\text { Post-accession } \\
\text { dummy }\end{array}$ & $0.08(0.09)$ & $0.03(0.02)$ & $\begin{array}{c}\text { Non-resident } \\
\text { applications at } \\
\text { national offices }\end{array}$ \\
$\begin{array}{l}\text { Post-accession } \\
\text { trend }\end{array}$ & $0.01(0.02)$ & 0.941 & $-1.21(0.35)^{* * *}$ \\
\hline Pseudo R-squared & 0.872 & $0.17(0.09)^{*}$ \\
\hline
\end{tabular}

Predicting aggregate patent grants

Dependent variable: granted patents by filing quarter

\begin{tabular}{|c|c|c|c|c|c|}
\hline & $\begin{array}{c}\text { EPO grants to } \\
\text { residents of } \\
\text { accession } \\
\text { countries }\end{array}$ & $\begin{array}{l}\text { EPO grants to } \\
\text { residents } \\
\text { validated in } \\
\text { accession } \\
\text { countries }\end{array}$ & $\begin{array}{c}\text { Resident grants } \\
\text { at national } \\
\text { offices }\end{array}$ & $\begin{array}{c}\text { EPO grants to } \\
\text { non-residents } \\
\text { validated in } \\
\text { accession } \\
\text { countries }\end{array}$ & $\begin{array}{l}\text { Non-resident } \\
\text { grants at } \\
\text { national offices }\end{array}$ \\
\hline $\begin{array}{l}\text { Post-accession } \\
\text { dummy }\end{array}$ & $0.29(0.13)^{* *}$ & $1.70(0.41)^{* * *}$ & $-0.16(0.05)^{* *}$ & $1.10(0.20)^{* * *}$ & $-1.06(0.38)^{* * *}$ \\
\hline $\begin{array}{l}\text { Post-accession } \\
\text { trend }\end{array}$ & $0.05(0.02)^{* * *}$ & $-0.15(0.16)$ & $0.01(0.01)$ & $-0.27(0.23)$ & $-0.19(0.06)^{* * *}$ \\
\hline $\mathrm{N}$ of observations & 336 & 336 & 288 & 336 & 288 \\
\hline $\mathrm{N}$ of countries & 14 & 14 & 12 & 14 & 12 \\
\hline Pseudo R-squared & 0.713 & 0.713 & 0.916 & 0.898 & 0.908 \\
\hline
\end{tabular}

All regressions include country and quarter-year dummies

Standard errors are robust and clustered on country.

Method of estimation is Poisson regression with robust standard errors

Our findings suggest that the impact on innovation by residents of accession countries may be muted, and also that there may be considerable inertia in their patenting strategies. Because EPO patenting from these countries rises so slowly, there is a good reason to think that access to markets outside the country is not severely limited by access to patent protection and that patent protection abroad more generally is not important for accession country firms. This conclusion must be tempered by the observation that patenting at the EPO is still considerably more costly than simply patenting at the national office. Apparently the prospect of greater market penetration on the basis of patent protection is not sufficient to overcome the cost differential.

\subsection{By technology field}

Next we briefly look at the aggregate patent filing behavior across technology fields to see if there are any differences in the response to accession to the EPC. We use the 35 technology classification proposed by Schmoch (2008), which is based on the International Patent 
Classification (IPC) codes. These are further aggregated into 5 broad technology classes: electrical engineering including computer technology, instruments, chemistry including pharmaceuticals, mechanical engineering, and other fields (primarily consumer goods and civil engineering). ${ }^{29}$

In general, we might expect that the average value of patents in a class might vary with the technology type, with patent protection of chemical inventions, especially pharmaceuticals being the most valuable (Hall, Jaffe, and Trajtenberg, 2005). However, recall that our earlier analysis suggested that the shift of patenting by residents of the accession countries to the EPO should be affected primarily by the cost of patenting at their home office, and not by the expected value of the patented invention. We find support for both of these ideas in the data: 1) non-residents are much more likely to patent chemical inventions than other inventions at the accession country offices before accession; and 2) residents are equally likely across technology classes to shift their patenting to the EPO after accession.

Figures $4 \mathrm{a}-4 \mathrm{c}$ illustrate the distribution of patent filings pre- and post-accession for residents of accession countries at the national offices and the EPO and for non-residents at the national offices. ${ }^{30}$ The resident filings at both offices show the same behavior across all the technology classes, with a decrease of about 300 patent filings per class at the national office and an increase of about 250 patent filings at the EPO. This provides some support to the argument that the primary determinant of the shift towards the EPO is not patent value. In contrast, before accession, non-resident patents are overwhelmingly in the chemical area $60 \%$ of all patent filings, Figure 4c). About half of these patent filings are in the biotechnology and pharmaceutical classes. In addition, about $20 \%$ of these filings are in the mechanical engineering area, which is the most active area for resident filings at the national offices. Thus before accession, non-residents are most concerned to protect their chemical and pharmaceutical inventions in these countries, but are also influenced to some extent by the technology profile of the countries. This can occur both because they may have inventions they wish to use in the country, or because they are concerned about local competition.

${ }^{29}$ Some patents (about 5\%) are classed in more than one technology class, even at the 5-technology level. We include these patents with a weight proportional to the number of technology classes in what follows. Given the small number of such patents, unweighted results are essentially the same.

${ }^{30}$ Recall that it is not meaningful to analyze non-resident filings at the EPO. 
Figure 4a

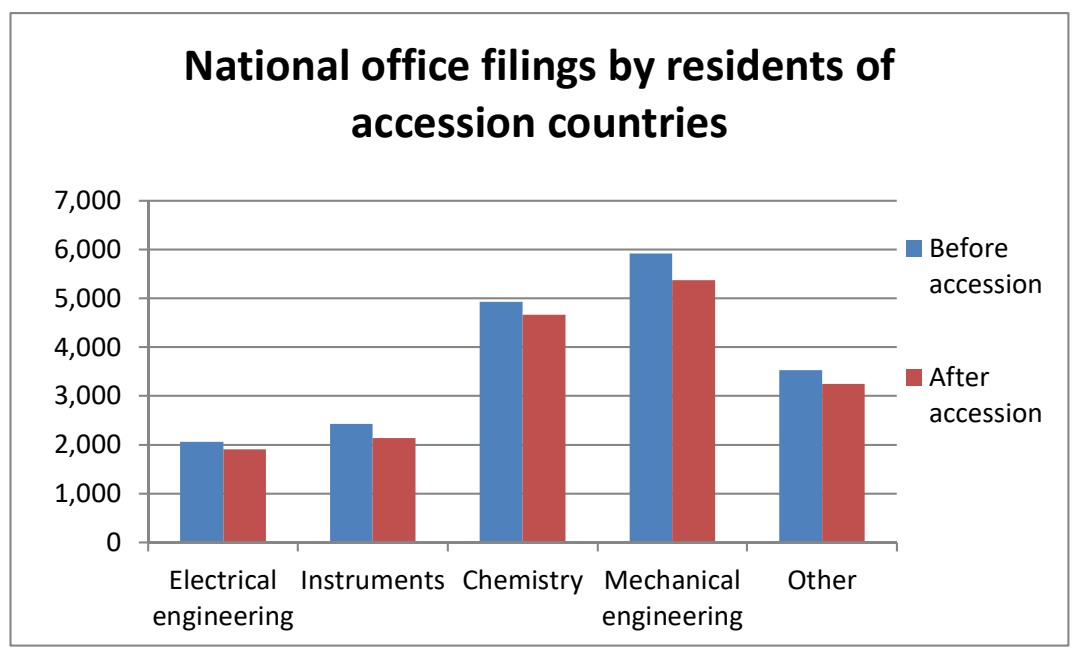

Figure 4b

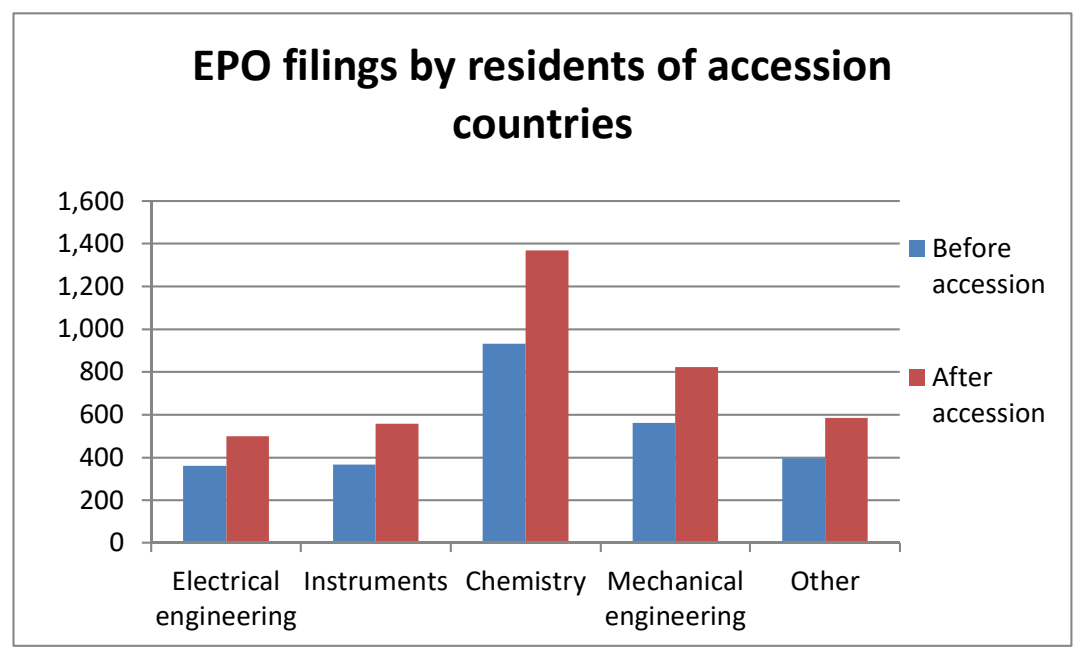

Figure 4c

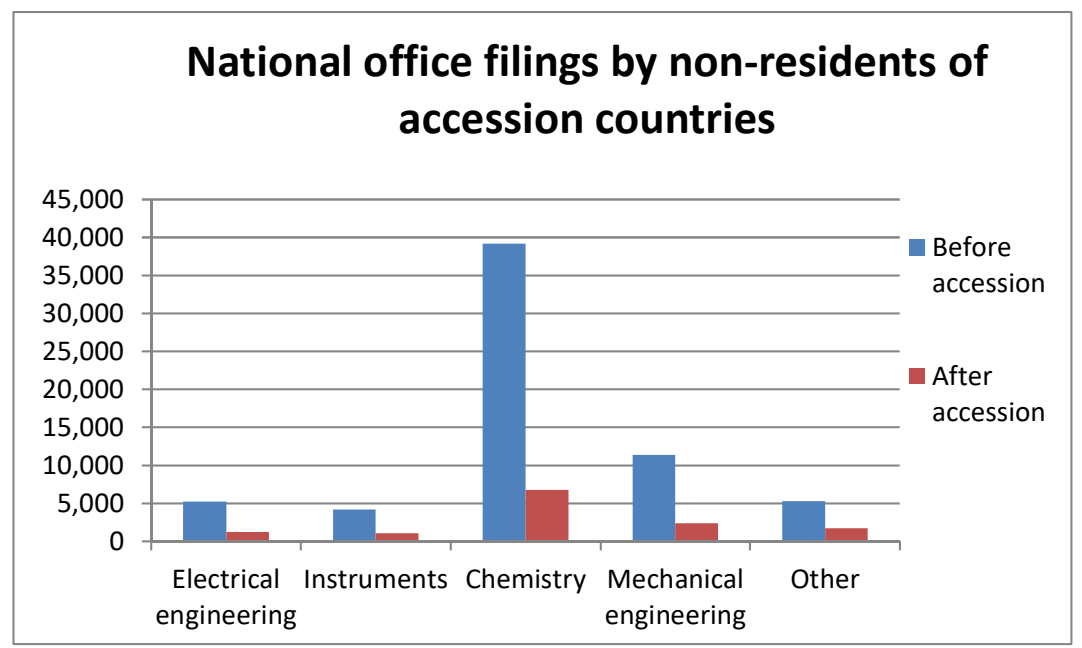


In order to quantify these results, and to control for differences across countries and over calendar time, we run regressions similar to those in the top panel of Table 4, by technology field. The results are shown in Table 5 below. In general, given the size of the standard errors, the trends for the different technology classes cannot be distinguished. Resident applications at the national offices fall slightly initially and then trend slowly upwards, while nonresident applications fall precipitously and then continue to decline, as we saw in the aggregate results. The only difference of note is that in chemistry the initial decline is slightly smaller and the trend larger, suggesting a slightly slower adjustment in this sector. Finally, there are too few EPO filings by residents of accession countries to discern any results of significance.

\section{Table 5}

Predicting aggregate patent applications by technology field

Dependent variable: patent filings in the quarter

336 obs $=14$ countries $\times 24$ quarters around accession date

\begin{tabular}{lccccc}
\hline & $\begin{array}{c}\text { Electrical } \\
\text { engineering }\end{array}$ & Instruments & Chemistry & $\begin{array}{c}\text { Mechanical } \\
\text { engineering }\end{array}$ & Other \\
\hline \multicolumn{7}{c}{ Resident applications at national offices } \\
Post-accession dummy & $-0.06(0.06)$ & $-0.12(0.06)^{* *}$ & $-0.14(0.08)^{*}$ & $-0.11(0.04)^{* * *}$ & $-0.02(0.08)$ \\
Post-accession trend & $0.03(0.03)$ & $0.03(0.03)$ & $0.04(0.02)^{*}$ & $0.04(0.02)^{* *}$ & $0.04(0.02)^{* *}$ \\
Pseudo R-squared & 0.755 & 0.781 & 0.856 & 0.867 & 0.846 \\
\hline \multicolumn{7}{c}{ Non-resident applications at national offices } \\
Post-accession dummy & $-1.42(0.15)^{* * *}$ & $-1.66(0.39)^{* * *}$ & $-1.24(0.38)^{* * *}$ & $-1.18(0.15)^{* * *}$ & $-1.19(0.26)^{* * *}$ \\
Post-accession trend & $-0.06(0.04)$ & $-0.13(0.05)^{* *}$ & $-0.30(0.11)^{* * *}$ & $-0.11(0.03)^{* * *}$ & $-0.10(0.05)^{* *}$ \\
Pseudo R-squared & 0.907 & 0.892 & 0.925 & 0.927 & 0.903 \\
\hline & \multicolumn{7}{c}{ EPO applications by residents } & $0.18(0.16)$ \\
Post-accession dummy & $0.10(0.33)$ & $0.26(0.26)$ & $-0.05(0.19)$ & $0.11(0.22$ \\
Post-accession trend & $0.05(0.06)$ & $0.01(0.03)$ & $-0.02(0.04)$ & $0.03(0.03)$ & $0.02(0.03)$ \\
Pseudo R-squared & 0.639 & 0.707 & 0.732 & 0.725 & 0.746 \\
\hline
\end{tabular}

Fractional counts are used for applications classed in more than one technological field.

All regressions include country and quarter-year dummies

Method of estimation is Poisson regression with robust standard errors, clustered on country.

\section{Accession country residents}

In this section we analyze changes in the behavior of accession country residents in more detail, in order to explore whether there are any real effects on innovation from accession to the EPC. We first analyze the patent filing behavior at the applicant-level, i.e. we track individual applicants over time (see Appendix C), and then use information on inventors to analyze any changes in inventive activity in accession countries more broadly.

\subsection{Applicant-level analysis}

In this section of the paper we ask whether resident applicants change their patenting behavior as a result of accession and also whether the number of resident applicants changes following accession. Hence, we ask whether the effects are driven by (the lack of) adjustments at the 
intensive (number of filings per applicant) and extensive (number of applicants) margin of patent filings.

Table 6 shows aggregate figures for different "applicant types" where we classify applicants into "types" according to their filing behavior as laid out in Table 1. At the aggregate level, we can check whether the total number of applicants has changed following accession and whether there has been change in the number of applicants across "applicant types." This provides a coarse way of verifying whether there have been any changes at the extensive margin. From the table, we can see that after accession both new and prior accession country resident patentees have shifted toward filing at the EPO and away from filing only at their own national office, although the latter is still by far the dominant strategy.

Table 6

Choice of patent application office by residents of accession countries

\begin{tabular}{|c|c|c|c|c|c|c|}
\hline $\begin{array}{l}\text { Number of entities applying for } \\
\text { patent(s) }\end{array}$ & $\begin{array}{r}\text { before } \\
\text { accession }\end{array}$ & $\begin{array}{r}\text { Number } \\
\text { after } \\
\text { accession, } \\
\text { prior } \\
\text { patenter }\end{array}$ & $\begin{array}{r}\text { after } \\
\text { accession, } \\
\text { new } \\
\text { patenter }\end{array}$ & $\begin{array}{r}\text { before } \\
\text { accession }\end{array}$ & $\begin{array}{r}\text { Shares } \\
\text { after } \\
\text { accession, } \\
\text { prior } \\
\text { patenter }\end{array}$ & $\begin{array}{r}\text { after } \\
\text { accession, } \\
\text { new } \\
\text { patenter }\end{array}$ \\
\hline Own national office only & 15,199 & 3,985 & 10,144 & $87.4 \%$ & $76.4 \%$ & $83.1 \%$ \\
\hline Other national offices only & 201 & 53 & 105 & $1.2 \%$ & $1.0 \%$ & $0.9 \%$ \\
\hline Both at own \& other national offices & 117 & 43 & 40 & $0.7 \%$ & $0.8 \%$ & $0.3 \%$ \\
\hline EPO only & 721 & 412 & 1,230 & $4.1 \%$ & $7.9 \%$ & $10.1 \%$ \\
\hline EPO \& own national office & 961 & 657 & 663 & $5.5 \%$ & $12.6 \%$ & $5.4 \%$ \\
\hline EPO \& other national offices & 31 & 19 & 7 & $0.2 \%$ & $0.4 \%$ & $0.1 \%$ \\
\hline EPO, own \& other national offices & 156 & 47 & 14 & $0.9 \%$ & $0.9 \%$ & $0.1 \%$ \\
\hline Not at the EPO & 15,517 & 4,081 & 10,289 & $89.2 \%$ & $78.2 \%$ & $84.3 \%$ \\
\hline At the EPO & 1,869 & 1,135 & 1,914 & $10.8 \%$ & $21.8 \%$ & $15.7 \%$ \\
\hline Total & 17,386 & 5,216 & 12,203 & & & \\
\hline
\end{tabular}

Before accession includes the 12 quarters prior to the quarter of accession to the EPO. After accession includes the accession quarter and 11 quarters following.

National offices are the national offices of the accession countries.

We are interested in resident entities' decisions to file for domestic or EPO patents and therefore focus in our empirical analysis the entities' choice of these two alternatives. We estimate standard patent production functions for filings with the domestic office and filings with the EPO. The coefficient of interest is obtained from the following (quasi-) differences-indifferences specification of a Poisson regression:

$$
p_{i c t} \sim f\left(\alpha_{i}+\delta_{t}+\gamma_{0} \text { accession }_{c t}+\gamma_{1} \text { accession }_{c t} \times t+X_{i c t} \beta\right)
$$

where $i=1, \ldots, N$, time $t=1, \ldots, T$, and country $c=1, \ldots, C$. In Equation (1), $p_{\text {ict }}$ denotes the number of patents (domestic or EPO) that firm $i$ in country $c$ in year $t$ applies for. Accession $_{c t}=1$ after a country acceded to the EPC and zero otherwise. The impact of accession is therefore captured by the coefficients $\gamma_{0}$ (level) and $\gamma_{1}$ (post-accession trend). $\alpha_{i}$ is an applicant-level random effect, $\delta_{t}$ a set of time dummies that absorb common time-specific shocks, and $X_{i c t}$ denotes a vector of (possibly) time-varying applicant-level characteristics. 
The sample is an unbalanced panel over the period 1995-2014 (up to 80 quarters of data for each applicant). Our analysis is based only on information we obtain from the patent data, which limits the amount of information we have for each applicant but avoids the (non-random) loss of data due to name-based matching to firm-level databases (which is especially problematic for our smaller accession countries and those countries with non-Roman character sets) - see Section 7. We assume that the applicant enters at the time of the first patent application during this period and we follow them until the end of the period. We only have a limited number of time-varying applicant-level variables, namely the applicant's total domestic and EPO patent stock (up until the quarter prior to the observation) and age (measured as counting from the year an applicant is observed to patent for the first time). Because of the variation in applicant age across applicants, the patent stock is normalized by age, which converts it to an average patenting rate prior to the current period. This procedure also has the advantage of quasi-orthogonalizing the two variables. Standard errors are clustered at the applicant level, which effectively means that a Poisson random effects model is being estimated.

The results of estimating the model above are given in Table 7. All estimates include a complete set of accession country and calendar year dummies. Both sets of dummies are highly significant, as patenting levels vary enormously across countries and there is a pronounced time trend underlying the patenting rates. The table has two panels: the top panel shows the estimates for national patent office applications for three types of entities: firms, individuals, and others, which includes various quasi-public entities such as universities, hospitals, and research institutes. The bottom panel shows the same thing for EPO patent applications. Not surprisingly, all the estimates show a very strong dependence on past patenting rates, whether at the national offices or the EPO. A one standard deviation increase in past patenting rates is associated with about a $120 \%-140 \%$ increase in patenting in the current period for all entity types.

Looking at the national office patenting first, one notes two things: first, residents slightly increase their patenting at national offices after accession to the EPC. The effect is driven by individuals and other entities (universities, research institutes, etc.), perhaps due to heightened awareness of the importance of patents given the accession. The trend estimate is two per cent growth per quarter with a small standard error. In addition, the quasi-public entities are more likely to continue to patent at the national offices if they were already patenting, possibly reflecting longstanding administrative requirements for local patenting.

The bottom panel shows quite different results for EPO patenting. All types of applicants show both a one-time increase in EPO applications post accession as well as a substantial trend, approximately 4 percent per quarter. This applicant-based result is somewhat in contrast with the aggregate result in Table 4, which showed no impact on filings at accession and a smaller and insignificant trend post-accession. The difference is doubtless due to heterogeneity in response across applicants of different size. In particular, smaller and newer applicants presumably have higher growth rates even if their patenting levels are low. Note also that individuals have a somewhat lower response to accession than firms and the other institutions; nevertheless, they do respond. 
Table 7

Predicting applicant-level patent applications

\begin{tabular}{lcccc}
\hline \multicolumn{5}{c}{$\begin{array}{c}\text { Dependent variable: National office patent applications by resident } \\
\text { entity during the quarter (1995-2014) }\end{array}$} \\
& All & Firms & Individuals & Other\# \\
\hline Post-accession dummy & 0.000 & 0.025 & $-0.105^{* * *}$ & -0.080 \\
& $(0.025)$ & $(0.055)$ & $(0.027)$ & $(0.095)$ \\
Post-accession trend & $0.018^{* * *}$ & 0.006 & $0.007^{* *}$ & $0.069^{* * *}$ \\
& $(0.002)$ & $(0.005)$ & $(0.002)$ & $(0.017)$ \\
D (entity patented before & $0.195^{* * *}$ & 0.038 & $-0.132^{* * *}$ & $0.540^{* * *}$ \\
accession) & $(0.032)$ & $(0.066)$ & $(0.028)$ & $(0.088)$ \\
Log (past patenting rate) & $1.388^{* * *}$ & $1.320^{* * *}$ & $1.283^{* * *}$ & $1.175^{* * *}$ \\
& $(0.020)$ & $(0.046)$ & $(0.013)$ & $(0.024)$ \\
\hline Observations & 930,049 & 215,088 & 687,132 & 27,829 \\
Entities & 27,606 & 6,611 & 20,177 & 820 \\
Share nonzero observations & $6.7 \%$ & $8.0 \%$ & $5.7 \%$ & $19.9 \%$ \\
Pseudo R-squared & 0.267 & 0.265 & 0.180 & 0.453 \\
\hline
\end{tabular}

Dependent variable: EP patent applications by accession country resident entity during the quarter (1995-2014)

\begin{tabular}{lcccc} 
& All & Firms & Individuals & Other\# \\
\hline Post-accession dummy & $0.473^{* * *}$ & $0.538^{* * *}$ & $0.272^{* *}$ & 0.133 \\
& $(0.077)$ & $(0.102)$ & $(0.086)$ & $(0.275)$ \\
Post-accession trend & $0.040^{* * *}$ & $0.035^{* * *}$ & $0.017^{* *}$ & 0.040 \\
& $(0.005)$ & $(0.007)$ & $(0.006)$ & $(0.024)$ \\
D (entity patented before & $1.178^{* * *}$ & $1.290^{* * *}$ & $0.526^{* * *}$ & $1.611^{* * *}$ \\
accession) & $(0.107)$ & $(0.118)$ & $(0.057)$ & $(0.262)$ \\
Log (past patenting rate) & $1.425^{* * *}$ & $1.361^{* * *}$ & $1.304^{* * *}$ & $1.184^{* * *}$ \\
& $(0.040)$ & $(0.056)$ & $(0.015)$ & $(0.050)$ \\
\hline Observations & 930,049 & 215,088 & 687,132 & 27,829 \\
Entities & 27,606 & 6,611 & 20,177 & 820 \\
Share nonzero observations & $1.2 \%$ & $2.5 \%$ & $0.8 \%$ & $2.1 \%$ \\
Pseudo R-squared & 0.305 & 0.349 & 0.232 & 0.292 \\
\hline
\end{tabular}

All regressions include dummies for the accession countries and quarter-years.

Method of estimation is Poisson with robust standard errors clustered on patenting entity.

Past patenting rate is lagged patent stock at the relevant office divided by age in quarters

\#Other includes government, universities, hospitals, and research institutes and academies.

We use the results of these regressions to evaluate the impact of accession to the EPO by estimating the counterfactual: what EPO and national patenting would have looked like if these countries had not acceded to the EPC. The results are shown in Figures 5a (national office filings) and $5 \mathrm{~b}$ (EPO filings). These graphs show the total patent applications by accession country residents, first at their national offices, and then at the EPO. The data points $(+s)$ and the solid line are the actual and fitted totals, and the dashed line is the total patent filings predicted when the post-accession dummy and trend are set to zero (the counterfactual). The national office regressions seem to suggest that national office applications would have fallen in the absence of accession, by about 600 applications per quarter after 6 years, whereas the EP regressions show a substantial increase, of about 400 applications per quarter after 6 years. So 
these graphs do suggest that residents have shifted some of their filings to the EPO as time as passed.

Figure 5a

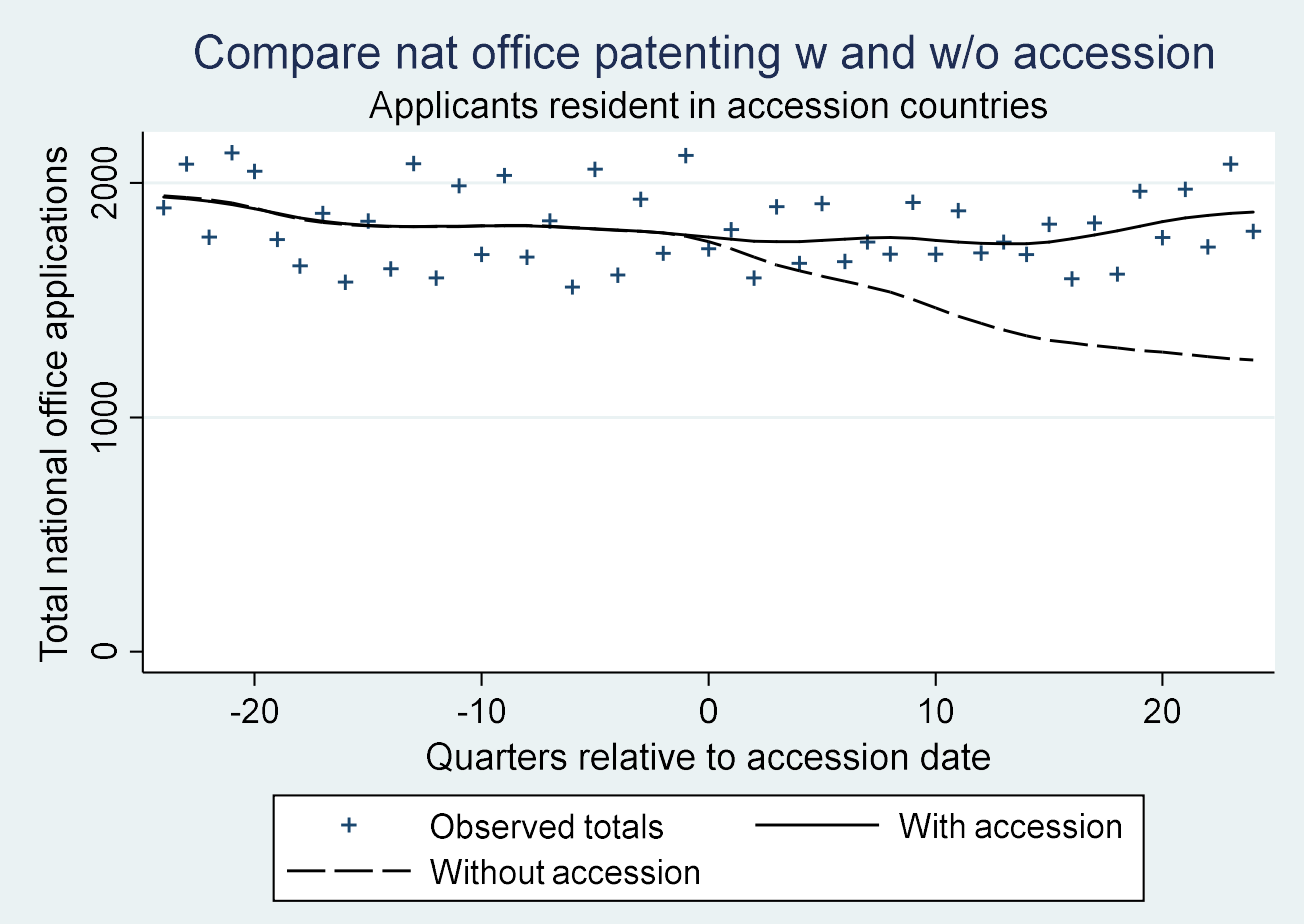

Figure 5b

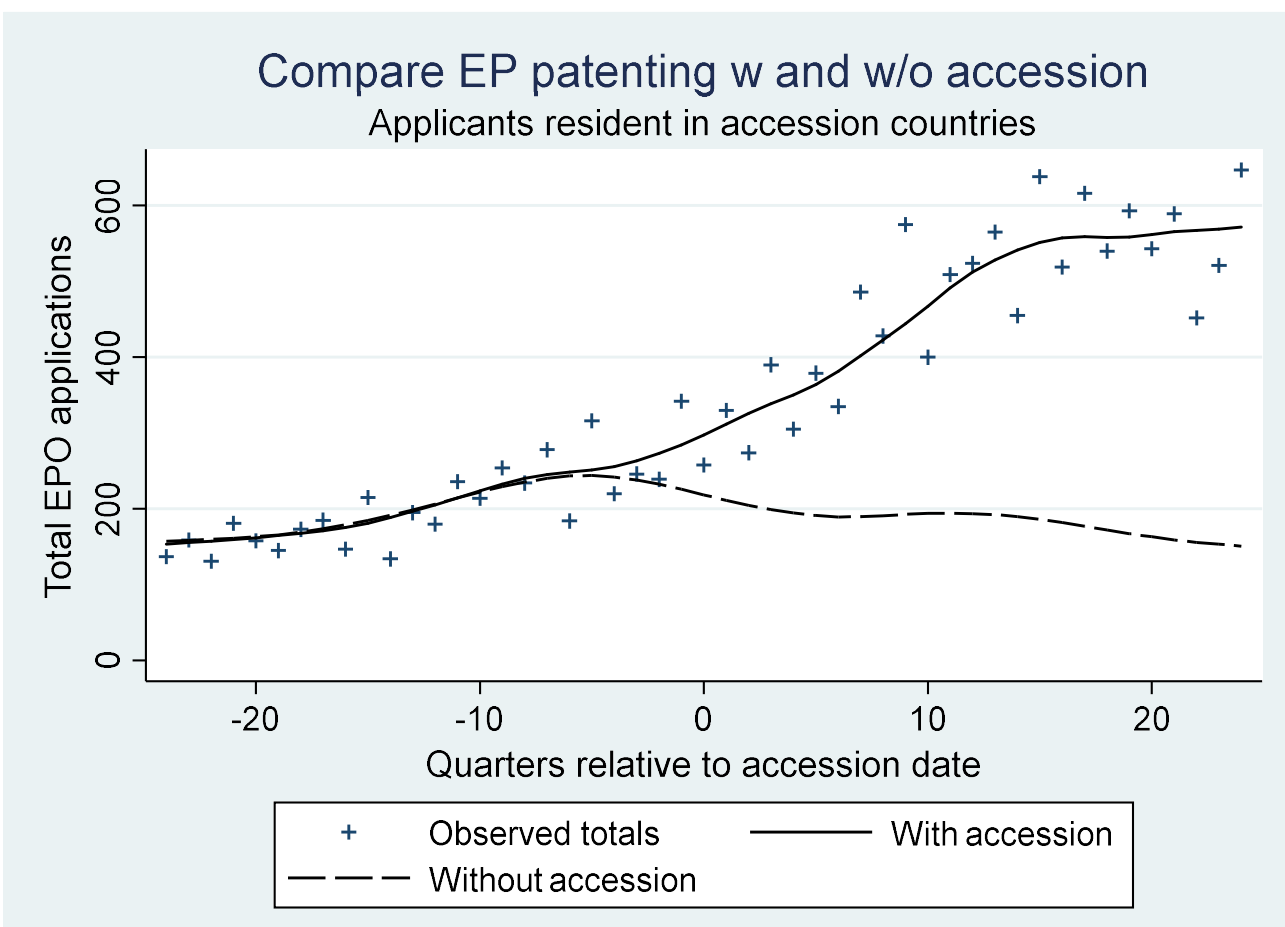




\subsection{Inventor-level analysis}

Next we investigate the important question of whether accession to the EPO leads to an increase in patented invention in the accession countries. A priori, we might expect effects of this kind to be small, because the reduction in patenting cost may be rather minor. On the other hand, becoming part of a major patent system may increase awareness of its benefits and provide an encouragement for invention. For this purpose, we define invention as a priority application by an inventor resident in an accession country, regardless of the location of the applicant listed on the application. Using priorities ensures that we count a patented invention only once, since a single invention can have multiple patent filings in different jurisdictions. Between priority years 1995 and 2013 there are 282,227 patent applications with accession country inventors, corresponding to 197,619 priority applications. ${ }^{31}$

Figures 6a (large countries) and 6b (small countries) show the behavior of priority patent filings by inventors in accession countries around the time of accession. For some countries, notably the Czech Republic, Poland, Turkey, Romania, and Slovenia, an increase in filings postaccession is visible, although there are few if any clear changes in trend. Other countries, such as Hungary, Bulgaria, etc., show little impact from accession to the EPC. Using Poisson regression and breaking things down between EPO, National office, and other office applications, we quantify these results in Table 8.

\section{Figure 6a}

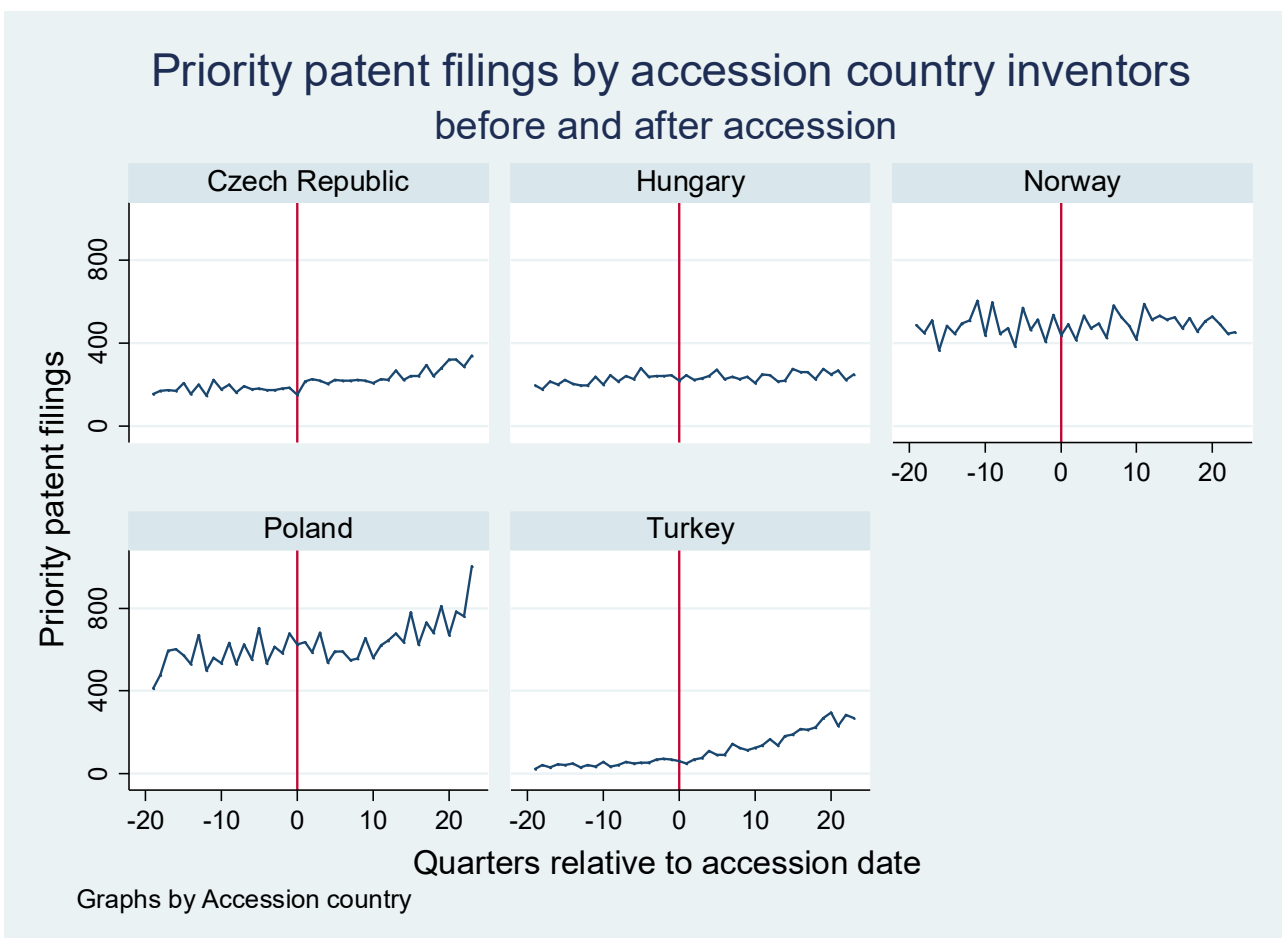

31 There are a few cases with inventors resident in both an accession and non-accession country; we include these but ignore the non-accession inventors that are also on the filing. When there are inventors from more than one country on an application, we use fractional weighting so that the weighted number of priorities equals the actual number. 


\section{Figure 6b}

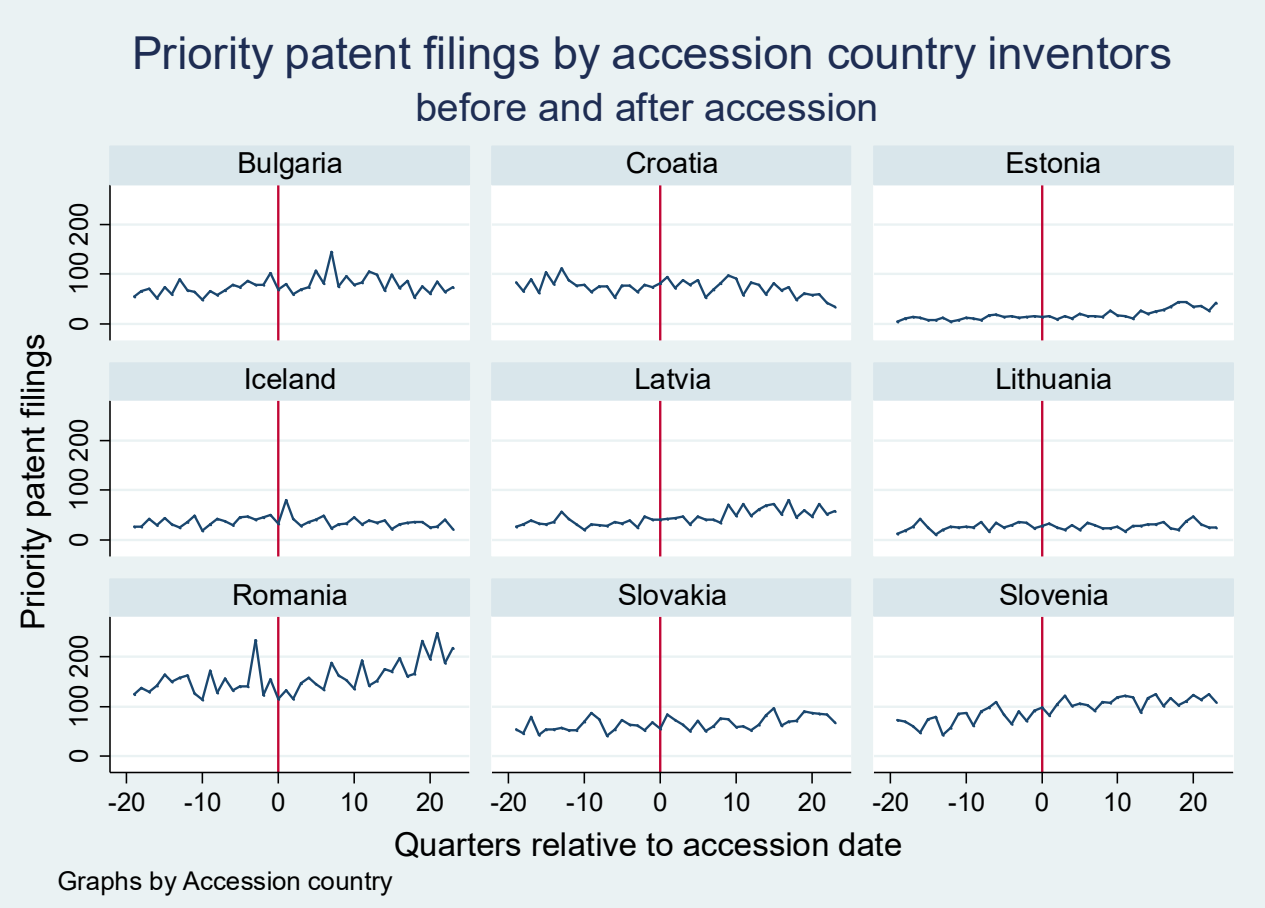

Table 8 presents the results of a Poisson regression for the number of patented inventions generated by inventors in an accession country as a function of the accession date. In these regressions we allow for a one time change in patenting level at accession as well as separate trends before and after accession. We also include country dummies to control for differing levels of patenting and quarter-year dummies to control for the overall trends in patenting. The first column shows the results for all priority patents while the next three columns break this down into filings at the EPO, filings at the national office, and filings at other offices. $70 \%$ of the other office filings are in the U.S., Canada, Germany, and Austria. Note that because a priority patent may be followed by applications in several offices, these three columns overlap to some extent. That is, the aggregate column focuses on invention behavior, whereas the next three columns also describe filing behavior for these inventors.

The first column shows the basic result: little trend in patented invention before accession, no significant increase at the accession time, but a substantial positive trend (2.6 per cent per quarter, or about 11 per cent per year) after accession. The interpretation is that accession to the EPC did have the effect of increasing patented invention in the accession country by increasing its growth rate, rather than inducing a one-time jump. This gradual change seems plausible, given that it takes time to invent, and it does suggest some kind of positive impact from accession to the EPC, albeit from a relatively low base.

The next three columns break this down into filing behavior. The post-accession trend is positive at all three offices and roughly equal in magnitude. There is no sign of a trend preaccession at the EPO or the other international offices. National office behavior does show 
striking differences: there is a substantial negative pre-accession trend as well as a one-time fall in patent filings at the time of accession. These results are doubtless due to the fact that many accession country inventors work for non-resident applicants, and we already saw that national office filings for this group simply collapsed.

\section{Table 8}

\section{Predicting aggregate patent filings by accession country inventors}

Dependent variable: log (patent filings by inventors resident in an accession country) 1064 obs $=14$ countries $\times 76$ quarters (1995-2013)

\begin{tabular}{|c|c|c|c|c|}
\hline & $\begin{array}{c}\text { All, priority apps } \\
\text { only }\end{array}$ & EPO applications & $\begin{array}{c}\text { Applications at } \\
\text { other offices }\end{array}$ & $\begin{array}{l}\text { Applications at } \\
\text { national offices }\end{array}$ \\
\hline Total filings* & 197,619 & 48,816 & 68,309 & 138,064 \\
\hline Pre-accession trend & $-0.009(0.006)$ & $-0.004(0.004)$ & $-0.002(0.003)$ & $-0.019(0.007)^{* * *}$ \\
\hline Post-accession dummy & $-0.203(0.090)^{* *}$ & $0.025(0.080)$ & $0.085(0.068)$ & $-0.296(0.121)^{* *}$ \\
\hline Post-accession trend & $0.026(0.010)^{* *}$ & $0.036(0.010)^{* * *}$ & $0.028(.006)^{* * *}$ & $0.029(0.010)^{* * *}$ \\
\hline Country dummies & yes & yes & yes & yes \\
\hline Quarter-year dummies & yes & yes & yes & yes \\
\hline Pseudo R-squared & 0.907 & 0.878 & 0.887 & 0.886 \\
\hline
\end{tabular}

Standard errors are robust and clustered on country.

Poisson estimation

* Filings will not add up because the aggregate in the first column counts each priority only once.

The conclusion from our analysis of inventor behavior in accession countries is that joining the EPC does seem to induce a slow growth in patented inventions produced by inventors in the country, as well as a shift towards patenting these inventions outside the country rather than at the national office. Compounding a $2.6 \%$ quarterly growth rate over three years yields a $36 \%$ increase in the level of priority patents from the 14 countries, which is about 1,440 additional patent inventions per quarter on top of the pre-accession rate of 4,000 per quarter, a nontrivial number.

\section{Non-residents}

The analysis above has shown that accession to the EPC has had only a modest effect on residents' patent filings at the EPO. In contrast, patent filings by non-residents react strongly to accession. In this section we analyze whether accession has affected the investment behavior of non-residents in accession countries as well as their patent filings.

One of the key arguments in favor of strengthening IP protection in developing countries is that it leads to more FDI (Lee and Mansfield, 1996), in particular in high-tech industries (Javorcik, 2004). Section 5.4 above shows that filings by non-residents with national offices are indeed concentrated in pharmaceuticals/chemistry and mechanical engineering, which are industries in which patents are considered more important (Cohen et al., 2000). Hence, a strengthening of patent protection in the form of accession to the EPC would affect non-resident companies in 
these industries and could therefore also affect their investment behavior. That said, there is also evidence to suggest that a strengthening of IP protection leads to more licensing of technology at the expense of FDI (Yang and Maskus, 2001).

We use the firm-level data described in Section 4 to analyze any changes in ownership of accession country firms by non-residents following accession. In contrast to existing studies on the link between FDI and IP protection which estimate the direct effect of broad indices of IP protection on FDI (e.g. Javorcik, 2004; Nunnenkamp and Spatz, 2004), we allow the effect of a strengthening of IP protection on FDI to work through non-resident patenting behavior. That is, we test whether ownership of accession country companies by non-residents changes as a function of changes in their patenting behavior following accession. We nevertheless control for any direct effect of accession on ownership by including the post-accession dummy and the dummy interacted with a time trend as in our previous specifications. We therefore estimate the following regression model:

$$
s_{i c t}=\alpha+\lambda_{i}+\delta_{t}+\gamma_{0} \text { accession }_{c t}+\gamma_{1} \text { accession }_{c t} \times t+\varphi_{0} p_{i c t}+v_{i c t}
$$

where $i=1, \ldots, N$ are non-resident parent companies, year $t=1, \ldots, T$, accession country $c=$ $1, \ldots, C$, accession $_{c t}=1$ after country $c$ acceded to the EPC and zero otherwise, $p_{i c t}$ denotes the number of EPO patents validated in accession country $c$ by parent company $i$ in year $t$ where validations can only occur post-accession, ownership share $s_{i c t}$ that non-resident firm $i$ holds of resident companies in accession country $c$ in year $t$. The specification also includes parent-firm fixed-effects $\lambda_{i}$ and year dummies $\delta_{t}$.

The data pose a number of challenges for our analysis. Perhaps the most important challenge concerns data coverage; the number of accession country firms available in Amadeus grows significantly over time and so does information on ownership structures. This make it difficult to infer changes of ownership structure over time. For example, if we observe non-resident company X to hold 51 per cent of ownership shares of accession country company $\mathrm{Y}$ in year $\mathrm{t}$ and $t+1$, we cannot necessarily infer that company $X$ held zero percent in $t-1$ as that information might simply be missing in the data. This limits our ability to track new investments over time and we exclude all firm-year observations with missing ownership share information. Another limitation is that ownership information is only available on an annual basis for the period 2000-2011; this leaves us with little data pre-accession especially for countries that acceded the EPC in 2002.32

Figure 7 shows average ownership shares held by non-residents of accession country companies over time. The figure distinguishes between patenting and non-patenting nonresidents. Note that for Figure 7, we exclude Norway and Iceland as they are at a much more economically advanced stage than the Eastern European accession countries (but we show regressions results including these in Table 9 below). We see in Figure 7 that patenting nonresidents on average hold a larger ownership stake, the difference is about 8 percentage points. When we look for changes in ownership shares over time, there is a clear positive trend.

${ }^{32}$ Note that our results reported in Table 9 are robust to dropping all countries that acceded in 2002. 
However, the trend appears to be similar for both patenting and non-patenting companies. Moreover, there is no obvious break in the trend following accession.

\section{Figure 7}

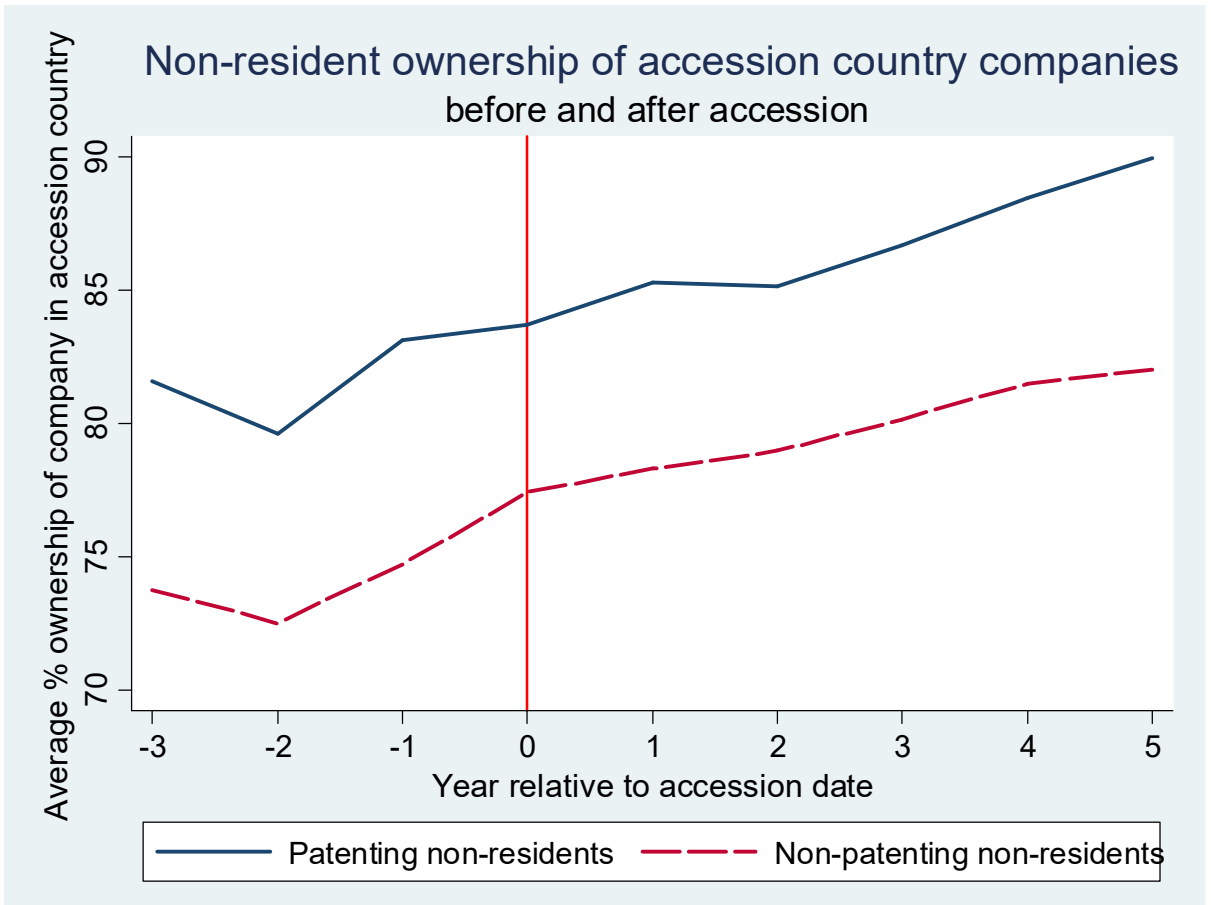

Note: the figure shows the average ownership share by non-resident companies of companies in accession countries (excluding Norway and Iceland).

Table 9 shows results from estimating equation (5) using OLS and including firm-level fixed effects. The first three columns show results for the entire set of accession countries for which BvD has data (which excludes Turkey). The last three columns exclude Norway and Iceland. The results suggest a positive association between the validation of EPO patents post-accession and increased ownership shares in those accession countries. However, the coefficient on the postaccession dummy variable is not significant in any of the specifications shown in Table 9. This indicates that accession as such had no direct, one-time effect on FDI. However, looking at the interaction of the post-accession dummy with a time trend, we see evidence that following accession, FDI grows over time in the sample that includes the more advanced economies Norway and Iceland. This is consistent with the notion that more advanced economies benefit through increased FDI from a strengthening of the patent system per se. In contrast, increases in FDI in the far less economically advanced accession states in our sample are only associated with changes in patenting behavior by foreign companies. Note however that the economic magnitude of this effect of patenting on FDI is very small. For example, the main coefficients of interest in columns (3) and (6) imply that a one standard deviation increase in the number of validated patents post-accession is associated with approximately only an increase of 0.15 percentage points in ownership shares. Hence, although we find evidence for a positive correlation between accession to the EPC and increased FDI, the relationship appears to be economically negligible. 
Table 9

\section{Predicting firm-level non-resident ownership}

Dependent variable: ownership share by non-resident company of resident company (2000-2011)

\begin{tabular}{lcccccc}
\hline & \multicolumn{3}{c}{ All countries } & \multicolumn{3}{c}{ excluding Norway and Iceland } \\
\hline Post-accession dummy & -0.148 & -0.187 & -0.169 & -0.151 & -0.194 & -0.182 \\
& $(0.184)$ & $(0.183)$ & $(0.184)$ & $(0.288)$ & $(0.288)$ & $(0.288)$ \\
Post-accession trend & $0.221^{* *}$ & $0.218^{* *}$ & $0.218^{* *}$ & -0.164 & -0.163 & -0.164 \\
& $(0.097)$ & $(0.097)$ & $(0.097)$ & $(0.299)$ & $(0.298)$ & $(0.299)$ \\
D (validated EPO patent) & & $1.147^{* *}$ & & & $0.927^{* *}$ & $(0.468)$ \\
& & $(0.045)$ & & & & $0.016^{*}$ \\
Number of validated & & & $0.018^{* *}$ & & & $(0.008)$ \\
EPO patents & & & $(0.008)$ & & & 102,671 \\
Observations & 135,957 & 135,957 & 135,957 & 102,671 & 102,671 & 30,990 \\
Entities & 39,398 & 39,398 & 39,398 & 30,990 & 30,990 & 0.013 \\
R-squared & 0.004 & 0.004 & 0.006 & 0.013 & 0.014 &
\end{tabular}

Method of estimation is OLS with robust standard errors clustered at firm-accession country-level.

All regressions include a complete set of entity and year dummies.

\section{Conclusion}

Our analysis offers empirical evidence on the effect of accession to the regional patent system created by the European Patent Convention on patent filings by entities in those countries as well as foreigners. Despite the substantial enlargement of the group of states signatory to the EPC over the last two decades and the importance of the EPC within the global patent system, so far there is no evidence on the impact of accession. This paper represents a first step towards filling this gap.

Our analysis suggests that accession to the EPC system did not result in significant changes in patenting with the national offices by residents of accession countries. They largely did not switch to the EPC system but instead continued filing with the domestic office. In a significant number of cases, they even filed for duplicate patent protection, filing applications for the same patent with both the domestic office and the EPO. That said, our analysis suggests that there was nevertheless a small increase in patent filings with the EPO by accession country residents. Although the magnitude of this effect is very small in absolute terms, it might nevertheless suggest some benefits to residents, especially because our analysis indicates that there is an increase in patentable inventions originating in the accession states. Non-residents switch immediately from national to EPO patents following accession. This indicates that most nonresidents that seek patent protection in accession states do so as part of a wider international patenting strategy and hence accession brings about cost savings.

Therefore, our analysis highlights the differential effect of accession to a regional patent system on residents and non-residents of the mostly smaller, less developed accession countries in our sample. Non-residents certainly benefit from the expansion of the regional patent system given their strong reaction, but the net effect on residents is a lot less clear. While we see a small increase in filings with the EPO by accession country residents, overall their low-level patenting activities remain unaffected by accession. This may suggest that most firms in our sample of 
accession countries are not yet at a stage where they actively use the patent system and accession to an international patent system did not change this substantially. 


\section{References}

Acharya Viral V., Ramin P. Baghai, and Krishnamurthy V. Subramanian (2014): "Wrongful Discharge Laws and Innovation," Review of Financial Studies, vol. 27(1), pages 301-346.

Bilir K., P. Moser, and I. Talis (2011): “Do Treaties Encourage Knowledge Transfer? Evidence from the Paris Convention," Available at SSRN: http://ssrn.com/abstract=1893052

Branstetter L., R. Fisman, and F. Foley (2006): “Do Stronger Intellectual property Rights Increase International Technology Transfer? Empirical Evidence From U.S. Firm-Level Panel Data," Quarterly Journal of Economics, Vol. 121, pp. 321-349.

Chen Y. and T. Puttitanum (2005): "Intellectual Property Rights and Innovation in Developing Countries," Journal of Development Economics, Vol. 78, pp. 474-493.

Cohen, W. M., R. R. Nelson, and J. Walsh (2000): “Protecting Their Intellectual Assets: Appropriability Conditions and Why U.S. Manufacturing Firms Patent (or Not)," Cambridge, MA: NBER Working Paper No. 7552.

Diwan I. and D. Rodrik (1991): "Patents, appropriate technology, and North-South trade," Journal of International Economics, Vol. 30, pp. 27-48.

Eurasian Patent Organization (2017): https://www.eapo.org/en/feature.html

European Patent Office (2015): Patstat database, April 2015 edition. Available at https://www.epo.org/searching-for-patents/business/patstat.html\#tab3

Feenstra, R. C., R. Inklaar and M. P. Timmer (2015): The Next Generation of the Penn World Table, American Economic Review, 105(10), 3150-3182, available for download at www.ggdc.net/pwt

Fink, C., M. Khan and H. Zhou (2016): Exploring the worldwide patent surge. Economics of Innovation and New Technology 25(2): 114-142.

FPA Patent Attorneys (2013). http://www.fpapatents.com/resource?id=220

Ginarte J. C. and W. G. Park (1997): "Determinants of patent rights: A cross-national study," Research Policy, Vol. 26, pp. 283-301.

Gould D. M. and W. C. Gruben (1996): "The role of intellectual property rights in economic growth," Journal of Development Economics, Vol. 48, pp. 323-350.

Hall B. H., C. Helmers, V. Sena (2013): “The importance (or not) of patents to UK firms," Oxford Economic Papers, Vol. 65(3), pp. 603-629.

Hall, B. H., A. Jaffe, and M. Trajtenberg (2005): "Market value and patent citations," Rand Journal of Economics 36 (1), pp. 16-38.

Harhoff, D., K. Hoisl, B. Reichl, and B. van Pottelsberghe (2009): "Patent Validation at the Country Level - the Role of Fees and Translation Costs," Research Policy, 38, pp. 14231437.

Helpman, E. (1993): “Innovation, Imitation, and Intellectual Property Rights," Econometrica, Vol. 61, pp. 1247-1280.

Herz, B. and M. Mejer (2016): “Reform of Trademark Protection in the European Union,” mimeo. 
Javorcik B. (2004): “The composition of foreign direct investment and protection of intellectual property rights: Evidence from transition economies," European Economic Review, Vol. 48 , pp. 39-62.

Kanwar S. and R. Evenson (2003): “Does Intellectual Property Protection Spur Technological Change?," Oxford Economic Papers, Vol. 55, pp. 235-264.

Lee J.-Y. and E. Mansfield (1996): Intellectual Property Protection and U.S. Foreign Direct Investment, The Review of Economics and Statistics, Vol. 78(2), pp. 181-186.

Lerner J. (2002): “150 Years of Patent Protection,” American Economic Review, Vol. 92, pp. 221225.

McCalman P. (2001): "Reaping what you sow: an empirical analysis of international patent harmonization," Journal of International Economics, Vol. 55, pp. 161-186.

Moser, P. (2005): "How Do Patent Laws Influence Innovation? Evidence from NineteenthCentury World's Fairs," American Economic Review, Vol. 95(4), pp. 1214-1236.

Nordhaus W. D. (1969): Invention, growth, and welfare: A theoretical treatment of technological change, MIT Press, Cambridge MA.

Nunnenkamp P. and J. Spatz (2004): "Intellectual Property Rights and Foreign Direct Investment: A Disaggregated Analysis," Review of World Economics, Vol. 140(3), pp. 393414.

Png I.P.L. (2017): “Law and Innovation: Evidence from State Trade Secrets Laws," Review of Economics and Statistics, Vol. 99(1), pp. 167-179.

Qian, Yi (2007): Do National Patent Laws Stimulate Domestic Innovation in a Global Patenting Environment? A Cross-Country Analysis of Pharmaceutical Patent Protection, 19782002. The Review of Economics and Statistics, Vol. 89(3), pp. 436-453.

Berger, R. (2004): Study on the Cost of Patenting, Report for the European Patent Office.

Sakakibara M. and L. Branstetter (2001): “Do Stronger Patents Induce More Innovation? Evidence from the 1988 Japanese Patent Law Reforms," RAND Journal of Economics, Vol. $32,771-1000$.

Scherer F. M. and S. Weisburst (1995): "Economics Effects of Strengthening Pharmaceutical Patent Protection in Italy," International Review of Industrial Property and Copyright Law, Vol. 26, pp. 1009-1024.

Schmoch U. (2008): “Concept of a Technology Classification for Country Comparisons,” WIPO, available at http://www.wipo.int/edocs/mdocs/classifications/en/ipc_ce_41/ipc_ce_41_5annex1.pdf (accessed February 2012)

Yang, G. and K. Maskus (2001): "Intellectual property rights and licensing: An econometric investigation," Weltwirtschaftiches Archiv, Vol. 137, pp. 58-79. 


\title{
NOT FOR PUBLICATION
}

\section{Online Appendices to "The impact of international patent systems: Evidence from accession to the European Patent Convention"}

\author{
Bronwyn H. Hall and Christian Helmers
}

\section{Appendix A: Extension and validation of EPO patents ${ }^{33}$}

This appendix describes how we determine whether an EPO patent grant has been extended to or validated in an accession country. This turns out not be straightforward, since not all validations generate a patent publication record and hence these validations can be missing in the legal status tables provided in the Patstat database.

\section{EPO patent extension and validation}

Patents granted by the EPO can take effect in countries that are not party to the EPC through extension agreements. The main difference between EPC member and extension states is that in the latter case, extending a European patent depends on national law and hence national extension rules whereas in the former case validation is regulated uniformly across member states by the EPC. In practice, however, extension rules are the same for all extension states. The extension fee is EUR 102 and payable to the EPO within six months counting from the date the European search report was published (or in case of Euro-PCT filings 31 months from the date of filing or earliest date of priority or six months from the date on which the international search report was published). To enter into force in an EPC or an extension state the patent then has to be validated in the target country after it has been granted by the EPO. Validation requires the payment of a fee, but the payment is not reported in the Patstat legal status tables.

More recently, the EPO also signed bilateral validation agreements, the first of which (with Morocco) entered into force in March 2015; these are not part of our analysis.

\section{Determining whether an EPO patent is validated}

We rely on legal status information to identify the countries designated by an EPO patent application and use information on patent renewals and lapses to determine whether a patent was actually validated in a given country. ${ }^{34}$ Validation occurs only after a patent has been

\footnotetext{
33 We are very grateful to Dietmar Harhoff for assistance in preparing this appendix.

${ }^{34}$ Legal status information is necessary because validation cannot be determined from equivalents, that is, from checking whether an EPO patent has national equivalents. Validated patents are only registered in national patent registers, which does not trigger a national patent publication that would be visible in Patstat. National equivalents are only visible when the national patent office requires a translation in accordance with Article 65(1) of the EPC. However, contracting states to the London Agreement do not necessarily require such translations. Among the countries included in our analysis, Croatia, Hungary, Iceland, Latvia, Lithuania, and Slovenia have ratified the London Agreement. Croatia, Hungary, and Iceland require only the translation of a patent's claims into their official language provided the European patent has been granted in English. Latvia, Lithuania, and Slovenia require a translation of the claims regardless of the language in which a patent was granted. Hence, relying on national equivalents, i.e.,
} 
granted. Given the average time lag between application and grant of about 43 months at the EPO (EPO Annual report 2009) and the fact that our data ends in 2015, we are left with a relatively short time series of post-accession EPO filings for which we can determine validation. Since validation only occurs after the granting of a patent, this limits the sample to EPO patents that have already been granted.

In all accession countries included in our sample, validation has to occur within three months upon grant by submitting a translation into the country's official language (see discussion in footnote 29). In order to determine whether an EPO-granted patent has been validated in a given accession state, we use information on the dates of register entry, renewal, withdrawal, expiry, and lapse from the Patstat legal status table (TLS221). About 70 per cent of the granted patents have at least one of these dates recorded in Patstat. Table A-1 provides some information on the legal status data available for the accession countries. We base the table on the total number of filings between the accession date for each country and the end of 2014 . The table shows the number of these filings that were granted, the number of eligible granted patents that had no information on the legal status file, and the number that were validated in that country.

\section{Table A-1}

Patent lapse data 2000-2014 for accession countries

\begin{tabular}{|c|c|c|c|c|c|c|c|c|}
\hline Code & Country & $\begin{array}{r}\text { EP patent } \\
\text { filings } 2000- \\
2014 \# \\
\end{array}$ & $\begin{array}{r}\text { Number } \\
\text { granted by } \\
2015 \\
\end{array}$ & $\begin{array}{r}\text { Share } \\
\text { granted }\end{array}$ & $\begin{array}{r}\text { Number } \\
\text { missing } \\
\text { info \% }\end{array}$ & $\begin{array}{r}\text { Share } \\
\text { missing } \\
\text { info }\end{array}$ & $\begin{array}{c}\text { Number } \\
\text { validated }^{*}\end{array}$ & $\begin{array}{r}\text { Share } \\
\text { grants } \\
\text { validated }\end{array}$ \\
\hline BG & Bulgaria & 551,965 & 468,131 & $84.8 \%$ & 190,733 & $40.7 \%$ & 83,108 & $17.8 \%$ \\
\hline $\mathrm{CZ}$ & Czech Republic & 551,965 & 468,131 & $84.8 \%$ & 140,763 & $30.1 \%$ & 11,635 & $2.5 \%$ \\
\hline $\mathrm{EE}$ & Estonia & 551,965 & 468,131 & $84.8 \%$ & 142,713 & $30.5 \%$ & 43,929 & $9.4 \%$ \\
\hline$H R$ & Croatia & 340,552 & 159,700 & $46.9 \%$ & 28,120 & $17.6 \%$ & 1,925 & $1.2 \%$ \\
\hline $\mathrm{HU}$ & Hungary & 533,600 & 438,660 & $82.2 \%$ & 206,077 & $47.0 \%$ & 212,544 & $48.5 \%$ \\
\hline IS & Iceland & 468,049 & 338,295 & $72.3 \%$ & 93,314 & $27.6 \%$ & 2,907 & $0.9 \%$ \\
\hline LT & Lithuania & 468,049 & 338,295 & $72.3 \%$ & 81,785 & $24.2 \%$ & 3,138 & $0.9 \%$ \\
\hline LV & Latvia & 438,475 & 295,322 & $67.4 \%$ & 67,724 & $22.9 \%$ & 1,164 & $0.4 \%$ \\
\hline NO & Norway & 340,552 & 159,700 & $46.9 \%$ & 27,736 & $17.4 \%$ & 625 & $0.4 \%$ \\
\hline PL & Poland & 496,235 & 380,567 & $76.7 \%$ & 107,522 & $28.3 \%$ & 11,416 & $3.0 \%$ \\
\hline RO & Romania & 533,600 & 438,660 & $82.2 \%$ & 138,298 & $31.5 \%$ & 7,847 & $1.8 \%$ \\
\hline SI & Slovenia & 543,078 & 453,598 & $83.5 \%$ & 171,573 & $37.8 \%$ & 44,541 & $9.8 \%$ \\
\hline SK & Slovakia & 551,965 & 468,131 & $84.8 \%$ & 141,383 & $30.2 \%$ & 5,734 & $1.2 \%$ \\
\hline \multirow[t]{2}{*}{$\mathrm{TR}$} & Turkey & 611,329 & 573,540 & $93.8 \%$ & 264,353 & $46.1 \%$ & 254,269 & $44.3 \%$ \\
\hline & Average & 498,670 & 389,204 & $78.0 \%$ & 128,721 & $33.1 \%$ & 48,913 & $10.1 \%$ \\
\hline
\end{tabular}

* Validation defined as at leasat one of lapse, renewal, withdrawal, expiry dates present and lapse date < one year from grant.

\# EP patents that were applied for between the accession date and the end of 2014.

$\%$ No information was available on the legal status file.

published translations of the complete patent specification, is likely to grossly and non-randomly underestimate validation. 
Most patent offices record non-validation as a lapse of the patent right shortly after the patent has been granted. To allow for some delay in the non-payment to be recorded, we take one year to be the relevant time period. If the lapse occurs after one year, we code the patent as originally validated and then lapsed (data as of October 2015). Employing this approach, we find that on average in 9 per cent of designated countries a given patent was eventually also validated, but there is substantial variation across countries. In several countries the validated shares are less than one per cent, but in Hungary and Turkey they are nearly one half. Although later accession means that there has been less time for action at the national office, not all of this variation can be attributed to variations in the date of accession. The most likely explanation is differences in reporting from different national offices, which means that our validation data may be somewhat unreliable.

Table A-2 repeats some of the analysis, restricting the time periods to the accession quarter and the following 12 quarters for each country. This minimizes the effects due to differences in the length of the time series for each firm. The differences in validation rates still persist, however.

Table A-2

Designation and validation for EPO patents in accession countries Accession quarter +12 following quarters

\begin{tabular}{|c|c|c|c|c|c|}
\hline Country & $\begin{array}{r}\text { Total EPO } \\
\text { filings* }\end{array}$ & $\begin{array}{r}\text { Granted by } \\
\text { Oct } 2015 \\
\end{array}$ & $\begin{array}{c}\text { Granted \& } \\
\text { validated }\end{array}$ & $\begin{array}{r}\text { Granted } \\
\text { share }\end{array}$ & $\begin{array}{r}\text { Validated } \\
\text { share of } \\
\text { grants }\end{array}$ \\
\hline Bulgaria & 541,553 & 208,658 & 32,439 & $38.5 \%$ & $15.5 \%$ \\
\hline Czech Republic & 541,553 & 208,658 & 8,423 & $38.5 \%$ & $4.0 \%$ \\
\hline Estonia & 541,553 & 208,658 & 41,026 & $38.5 \%$ & $19.7 \%$ \\
\hline Croatia & 578,825 & 140,670 & 1,871 & $24.3 \%$ & $1.3 \%$ \\
\hline Hungary & 549,302 & 205,294 & 101,931 & $37.4 \%$ & $49.7 \%$ \\
\hline Iceland & 587,440 & 194,102 & 2,169 & $33.0 \%$ & $1.1 \%$ \\
\hline Lithuania & 587,440 & 194,102 & 2,284 & $33.0 \%$ & $1.2 \%$ \\
\hline Latvia & 590,914 & 185,684 & 1,041 & $31.4 \%$ & $0.6 \%$ \\
\hline Norway & 578,825 & 140,670 & 614 & $24.3 \%$ & $0.4 \%$ \\
\hline Poland & 570,538 & 198,905 & 9,477 & $34.9 \%$ & $4.8 \%$ \\
\hline Romania & 549,302 & 205,294 & 5,722 & $37.4 \%$ & $2.8 \%$ \\
\hline Slovenia & 547,962 & 207,938 & 11,487 & $37.9 \%$ & $5.5 \%$ \\
\hline Slovakia & 541,553 & 208,658 & 3,883 & $38.5 \%$ & $1.9 \%$ \\
\hline Turkey & 537,028 & 226,229 & 83,587 & $42.1 \%$ & $36.9 \%$ \\
\hline Average & 560,271 & 195,251 & 21,854 & $35.0 \%$ & $10.4 \%$ \\
\hline
\end{tabular}

* Total filings at the EP during the quarter of the country's accession and the subsequent 12 quarters

Figures A-1 and A-2 look at the validation behavior of residents and non-residents with the EPO. For this analysis we restrict the sample of patent filings with the EPO to patents that have been granted. A complication is that both residents and non-residents validate in a range of accession countries, and because accession dates vary, it is not possible to generate an aggregate figure for non-residents that is exactly parallel to the figure for residents. Therefore for non-residents, we look at each accession country separately, which eliminates the accession date timing problem. 
For residents of accession countries, we focus on validation in their home country, which eliminates the timing problem.

Figure A- 1 shows that EPO filings by accession country residents do rise slightly after accession, albeit from a low level. About half of these filings are granted by the end of 2013, and the share of the grants validated in the accession country is constant at about 60 per cent. That is, a fair number of these granted EPO patents are not validated in their own country, casting some doubt on the role of accession in the uptake of EPO filings by accession country residents.

\section{Figure A-1: EPO patent filings by residents (by quarter)}

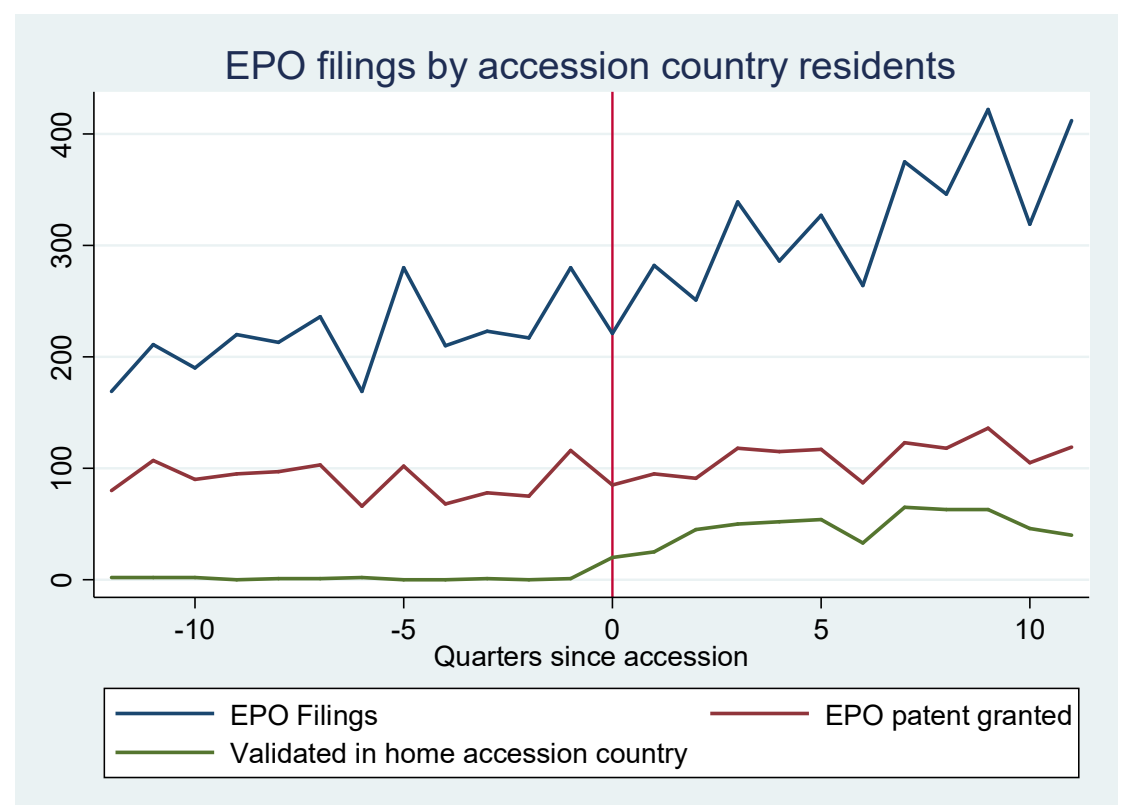

Note: time is the application quarter of an EPO patent relative to the accession date of the relevant country.

Figure A-2 shows the data for non-residents, country by country. This figure shows the share of granted EPO patents that are validated in each of the 14 accession countries. From the figure, one can see that in some cases (Hungary and Turkey) non-residents of the accession countries are about as likely as residents to validate a granted patent in that country. However, validation rates are quite a bit lower in most of the countries. We do not know why, but it may be related to the aforementioned quality issues with our validation data. 


\section{Figure A-2: EPO patent filings by non-residents (by quarter)}

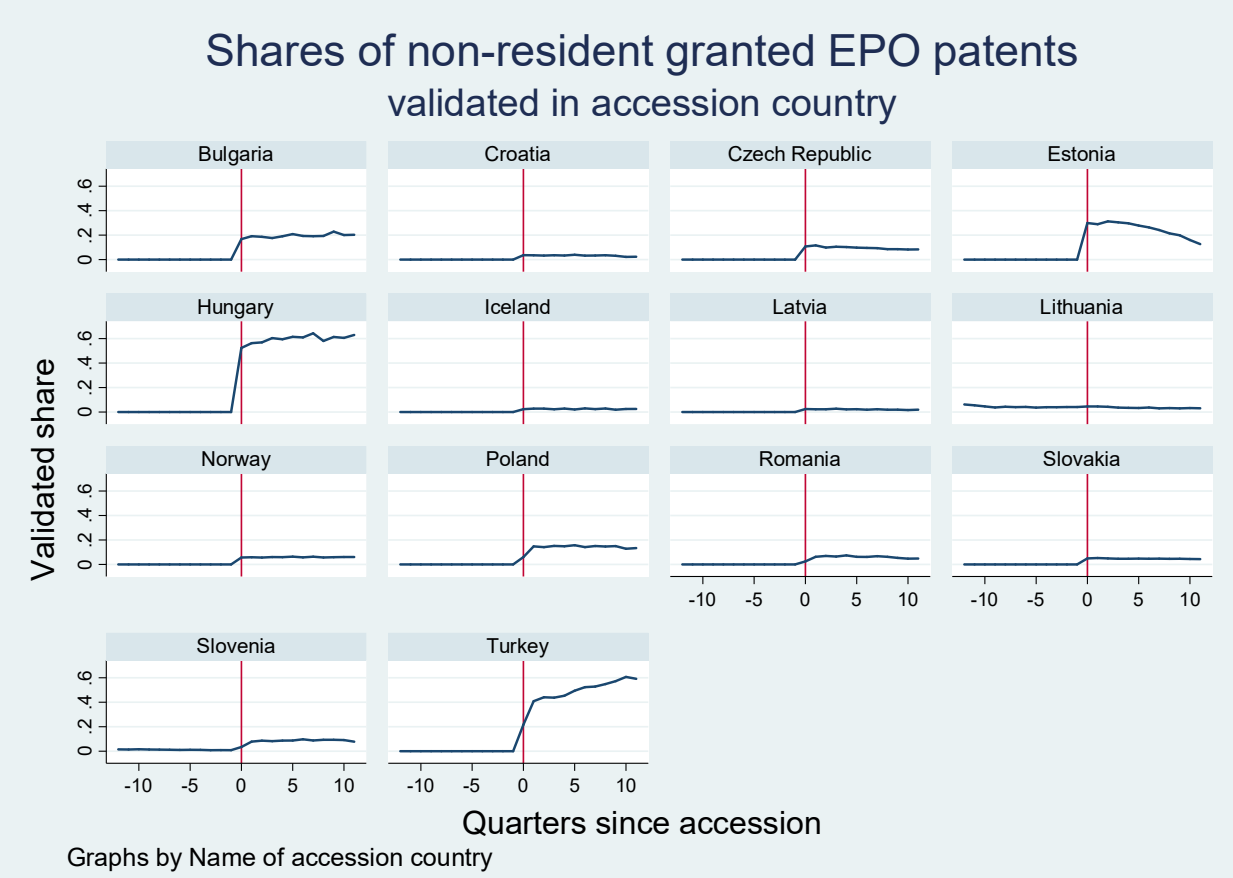

Note: time is the application quarter of an EPO patent relative to the accession date of the relevant country.

\section{Appendix B: A simple model of the impact of accession}

To illustrate the effect of accession on patent filing behavior slightly more formally, let the incremental value of a patent in each European country be denoted $V_{i}$ and the cost of patenting be denoted $C_{i}$ with countries denoted $i=0,1, \ldots, J$. The value and cost of domestic patenting are $V_{0}$ and $C_{0}$. A firm will take out a patent in every country where $V_{i}-C_{i}>0$, with one complication due to the fact that the EPO is cheaper after a certain point. Assume that $V_{0}-C_{0}$ is larger than all the others. That is, if a domestic firm patents at all, it patents in its home country (which is supported by our data as shown in Section 5.1 below). We disregard maintenance fees in our analysis because they are the same regardless of the route through which patent protection is obtained. We also disregard any differences in legal fees across the two patenting strategies. 35

Before accession to the EPC, firms make the following computation when they decide whether to patent domestically:

$$
V_{0}-C_{0}>0
$$

\footnotetext{
${ }^{35}$ Alternatively, we could include the legal fees in the cost variable, which would mean that we can no longer use the patent office fee schedules to calibrate it. It is likely that legal fees for applying at the EPO exceed those for domestic offices. However, if an applicant wants to pursue applications at several national offices, legal and translation fees could be substantial.
} 
In contrast, their decision to obtain an EPO patent or instead to patent directly with the individual national patent offices is determined by the following condition (assuming that $\left.\sum_{i}^{J}\left(V_{i}-C_{i}\right)>0\right)$ :

$$
\sum_{i=1}^{J} V_{i}-C_{E P O}>\sum_{i=1}^{J}\left(V_{i}-C_{i}\right)
$$

Which is to say that firms choose the EPO route if the net value of taking out a patent with the EPO exceeds the sum of the net values of obtaining patent rights with the individual offices. After accession, expression (2) changes into

$$
\begin{gathered}
V_{0}+\sum_{i=1}^{J} V_{i}-C_{E P O}>V_{0}-C_{0}+\sum_{i=1}^{J}\left(V_{i}-C_{i}\right) \\
\text { or } C_{0}+\sum_{i}^{J} C_{i}-C_{E P O}>0
\end{gathered}
$$

If the value of a patent and fees stay the same after accession, then the effect of accession works exclusively through $C_{0}$, that is, for sufficiently large costs at the domestic patent office, firms choose an EPO patent over several national patents including a patent with their domestic patent office.

Then the main question is for which number $J$, expressions (2) and (3) hold. If for illustration we assume that the threshold is $J \geq 3$, this means that for $J=1$ or 2 , domestic firms only wanted to patent in one or two countries in addition to their own before accession. After accession, domestic patenting enters the set $J$, which means that patentees that were formerly patenting in only $J=2$ countries, find themselves at the threshold level $J \geq 3$ after accession. This in turn means that expression (3) holds and these firms will choose an EPO patent instead of patenting separately at each national patent office. Hence, our simple analysis implies that for $J=1$ and domestic patenting before accession, EPO accession will not affect domestic firms' patenting strategies for most inventions. That is, if firms only wanted to patent in one or two countries in addition to their own before accession, accession does not change this.

\section{Appendix C: Applicant names and types}

Table 1 in the main text defines 3 different applicant types before accession to the EPC and 4 types post accession depending on whether a given applicant files with the national office, the EPO validating the European patent only outside of the accession country, or also in the accession country. The definition of these applicant types requires uniquely identifying applicants (i.e. associating different patent filings at the national office and the EPO by the same applicant to the applicant where the same applicant can appear under different names or variations of the same name for a range of different reasons, for a more detailed description of these problems see Helmers et al., 2010). This involves the well-known problem of name harmonization (Thoma et al., 2010). We address this problem by using a combination of Patstat's (version October 2015) own name harmonization in form of the doc_std_name_id variable of Table TLS206_PERSON, OECD's HAN database (version February 2015), our own string harmonization code, as well as very extensive manual checking and cleaning (we checked 
over 20,000 applicant names manually). Applicants are defined as residents/non-residents according to the country code reported by Patstat for the applicant.

\section{References}

Helmers Christian, Mark Rogers and Philipp Schautschick (2010). Intellectual Property at the Firm-Level in the UK: The Oxford Firm-Level Intellectual Property Database, Oxford University, Department of Economics Discussion Paper No. 546.

OECD, HAN database, February 2015

Thoma Grid, Salvatore Torrisi, Alfonso Gambardella, Dominique Guellec, Bronwyn Hall, and Dietmar Harhoff (2010). Harmonizing and Combining Large Datasets - An Application to Firm-Level Patent and Accounting Data, NBER Working Paper No. 15851. 


\section{Appendix D: Supplementary Tables and Figures}

Table D-1

\begin{tabular}{|c|c|c|c|}
\hline Code & Country & Accession date & $\begin{array}{l}\text { PPP-adj GDP per } \\
\text { capita in } 2005 \#\end{array}$ \\
\hline $\mathrm{BE}$ & Belgium & 7-Oct-77 & 33,893 \\
\hline FR & France & 7-Oct-77 & 31,230 \\
\hline DE & Germany & 7-Oct-77 & 31,657 \\
\hline LU & Luxembourg & 7-Oct-77 & 73,243 \\
\hline NL & Netherlands & 7-Oct-77 & 36,402 \\
\hline $\mathrm{CH}$ & Switzerland & 7-Oct-77 & 36,994 \\
\hline GB & United Kingdom & 7-Oct-77 & 33,983 \\
\hline SE & Sweden & 1-May-78 & 33,959 \\
\hline IT & Italy & 1-Dec-78 & 29,562 \\
\hline AT & Austria & 1-May-79 & 36,151 \\
\hline LI & Liechtenstein & 1-Apr-80 & NA \\
\hline GR & Greece & 1-Oct-86 & 25,308 \\
\hline ES & Spain & 1-Oct-86 & 28,325 \\
\hline DK & Denmark & 1-Jan-90 & 34,677 \\
\hline MC & Monaco & 1-Dec-91 & NA \\
\hline PT & Portugal & 1-Jan-92 & 19,949 \\
\hline IE & Ireland & 1-Aug-92 & 40,247 \\
\hline $\mathrm{FI}$ & Finland & 1-Mar-96 & 32,293 \\
\hline CY & Cyprus & 1-Apr-98 & 18,240 \\
\hline TR & Turkey & 1-Nov-00 & 9,532 \\
\hline BG & Bulgaria & 1-Jul-02 & 8,904 \\
\hline $\mathrm{CZ}$ & Czech Republic & 1-Jul-02 & 20,347 \\
\hline $\mathrm{EE}$ & Estonia & 1-Jul-02 & 15,962 \\
\hline SK & Slovakia & 1-Jul-02 & 15,376 \\
\hline SI & Slovenia & 1-Dec-02 & 22,909 \\
\hline HU & Hungary & 1-Jan-03 & 16,476 \\
\hline RO & Romania & 1-Mar-03 & 8,137 \\
\hline PL & Poland & 1-Mar-04 & 13,250 \\
\hline IS & Iceland & 1-Nov-04 & 40,448 \\
\hline LT & Lithuania & 1-Dec-04 & 13,068 \\
\hline LV & Latvia & 1-Jul-05 & 12,031 \\
\hline MT & Malta & 1-Mar-07 & 20,314 \\
\hline$H R$ & Croatia & 1-Jan-08 & 14,028 \\
\hline NO & Norway & 1-Jan-08 & 49,293 \\
\hline MK & FYROM & 1-Jan-09 & 6,573 \\
\hline SM & San Marino & 1-Jul-09 & NA \\
\hline $\mathrm{AL}$ & Albania & 1-May-10 & 4,939 \\
\hline RS & Serbia & 1-Oct-10 & 7,177 \\
\hline
\end{tabular}

\# Source: Heston et al. (2012) Penn World Tables. Gray shaded countries are included in our analysis. 
Table D-2

Fee overview

\begin{tabular}{|c|c|c|c|c|c|c|c|c|c|c|c|}
\hline \multirow[t]{2}{*}{ Country } & \multirow{2}{*}{$\begin{array}{c}\text { Validation } \\
\text { Fees }\end{array}$} & \multicolumn{10}{|c|}{ Renewal Fees at national office (Year) } \\
\hline & & 1 & 2 & 3 & 4 & 5 & 6 & 7 & 8 & 9 & 10 \\
\hline Bulgaria & 26 & & & 26 & 26 & 77 & 102 & 128 & 153 & 204 & 255 \\
\hline Czech Rep & 16 & 33 & 33 & 33 & 33 & 66 & 66 & 66 & 66 & 98 & 131 \\
\hline Estonia & 32 & 26 & 26 & 64 & 77 & 96 & 115 & 134 & 153 & 179 & 205 \\
\hline Hungary & $87 *$ & 87 & 87 & 87 & 87 & 87 & 87 & 87 & 87 & 87 & 87 \\
\hline Iceland & & 96 & 96 & 96 & 108 & 120 & 132 & 144 & 162 & 180 & 198 \\
\hline Latvia & 36 & & & 86 & 129 & 143 & 150 & 172 & 215 & 258 & 322 \\
\hline Lithuania & $46 * *$ & 46 & 46 & 46 & 46 & 46 & 46 & 46 & 46 & 46 & 46 \\
\hline Poland & 22 & 117 & 117 & 117 & 61 & 73 & 86 & 98 & 110 & 135 & 159 \\
\hline Romania & 60 & & & 150 & 160 & 180 & 200 & 220 & 240 & 260 & 280 \\
\hline Slovakia & 7 & & & 66 & 83 & 100 & 116 & 133 & 149 & 166 & 199 \\
\hline Slovenia & & & & 30 & 34 & 42 & 50 & 60 & 70 & 80 & 110 \\
\hline Turkey & 169 & & 73 & 78 & 86 & 143 & 153 & 191 & 199 & 213 & 247 \\
\hline
\end{tabular}

Notes:

All values in Euros

* plus EUR 13 for sixth and each subsequent page

** plus EUR 11 for the 11th and each subsequent claim

Source: National Law Relating to the EPC (15th edition) 


\section{Table D-3}

Predicting Accession to the EPC

Cox hazard rate regression for accession

\begin{tabular}{lccc}
\hline & Coefficient & Standard error & Clustered s.e. \\
\hline Lagged $\log ($ population) & 0.125 & $(0.261)$ & $(0.233)$ \\
Lagged $\log ($ real GDP/pop) & -0.388 & $(1.054)$ & $(1.070)$ \\
Lagged $\log ($ patent apps/pop) & -0.037 & $(0.339)$ & $(0.343)$ \\
Chi-squared (deg of freedom) & & $1.39(3)$ & $3.85(3)$ \\
\hline
\end{tabular}

119 annual observations on 14 accession countries.

Patent applications are filings at the national patent office

Time period is $1995-2008$

\section{Table D-4}

Companies registered in accession countries available in BvD Amadeus

\begin{tabular}{|c|c|c|c|c|c|}
\hline \multirow[t]{2}{*}{ Country } & \multicolumn{3}{|c|}{ Accession country firms } & \multicolumn{2}{|c|}{$\begin{array}{c}\% \text { of foreign owned } \\
\text { companies with ownership }\end{array}$} \\
\hline & \# all & $\begin{array}{c}\text { \#foreign } \\
\text { ownership share }>0\end{array}$ & $\begin{array}{c}\text { \% foreign } \\
\text { ownership share }>0\end{array}$ & $>50 \%$ & $100 \%$ \\
\hline Bulgaria & 233,354 & 1,267 & $0.54 \%$ & $74.66 \%$ & $49.17 \%$ \\
\hline Croatia & 24,952 & 749 & $3.00 \%$ & $83.58 \%$ & $68.76 \%$ \\
\hline Czech Republic & 121,452 & 5,413 & $4.46 \%$ & $88.88 \%$ & $73.19 \%$ \\
\hline Estonia & 91,139 & 2,728 & $2.99 \%$ & $79.47 \%$ & $65.36 \%$ \\
\hline Hungary & 385,967 & 2,279 & $0.59 \%$ & $78.37 \%$ & $42.04 \%$ \\
\hline Iceland & 28,269 & 263 & $0.93 \%$ & $60.08 \%$ & $47.15 \%$ \\
\hline Latvia & 10,322 & 841 & $8.15 \%$ & $85.02 \%$ & $69.08 \%$ \\
\hline Lithuania & 15,515 & 949 & $6.12 \%$ & $77.98 \%$ & $55.74 \%$ \\
\hline Norway & 297,843 & 8,501 & $2.85 \%$ & $78.90 \%$ & $70.77 \%$ \\
\hline Poland & 93,385 & 7,828 & $8.38 \%$ & $87.08 \%$ & $63.77 \%$ \\
\hline Romania & $1,196,861$ & 7,486 & $0.63 \%$ & $74.04 \%$ & $39.85 \%$ \\
\hline Slovakia & 17,904 & 1,488 & $8.31 \%$ & $90.46 \%$ & $70.16 \%$ \\
\hline Slovenia & 51,784 & 537 & $1.04 \%$ & $78.40 \%$ & $59.40 \%$ \\
\hline
\end{tabular}




\section{Table D-5}

Filings by country before and after accession

\begin{tabular}{|c|c|c|c|c|c|c|}
\hline \multirow[b]{3}{*}{ Country } & \multicolumn{4}{|c|}{$\begin{array}{l}\text { Patents applied for at National Offices before and } \\
\text { after accession }\end{array}$} & \multirow{2}{*}{\multicolumn{2}{|c|}{$\begin{array}{c}\text { Accession country filings } \\
\text { at the EPO before and } \\
\text { after accession } \\
\text { Residents }\end{array}$}} \\
\hline & \multicolumn{2}{|c|}{ Residents } & \multicolumn{2}{|c|}{ Non-residents } & & \\
\hline & Before & After & Before & After & Before & After \\
\hline Bulgaria & 1,098 & 783 & 3,351 & 1,446 & 19 & 55 \\
\hline CzechRepublic & 1,679 & 1,791 & 11,619 & 904 & 140 & 270 \\
\hline Estonia & 62 & 88 & 2,058 & 67 & 18 & 19 \\
\hline Croatia & 672 & 608 & 844 & 178 & 101 & 71 \\
\hline Hungary & 2,781 & 2,502 & 10,767 & 389 & 300 & 363 \\
\hline Iceland & 143 & 118 & 1,260 & 1,113 & 93 & 95 \\
\hline Lithuania & 227 & 201 & 133 & 116 & 11 & 18 \\
\hline Latvia & 289 & 371 & 144 & 113 & 14 & 36 \\
\hline Norway & 3,763 & 3,215 & 15,124 & 7,300 & 1,348 & 1,491 \\
\hline Poland & 6,552 & 6,205 & 15,629 & 1,788 & 170 & 368 \\
\hline Romania & 1,595 & 1,161 & 362 & 141 & 21 & 45 \\
\hline Slovenia & 709 & 863 & 289 & 96 & 110 & 255 \\
\hline Slovakia & 584 & 495 & 5,058 & 290 & 28 & 63 \\
\hline Turkey & 232 & 652 & 1,805 & 523 & 52 & 152 \\
\hline Total & 20,386 & 19,053 & 68,443 & 14,464 & 2425 & 3301 \\
\hline
\end{tabular}

Before is defined as 12 quarters prior to the accession date and after as 12 quarters including the accession date. 


\section{Table D-6}

Predicting aggregate patent applications

Dependent variable: patent filings in the quarter 1064 obs $=14$ countries $\times 76$ quarters (1995-2013)

\begin{tabular}{|c|c|c|c|}
\hline & $\begin{array}{c}\text { EPO applications } \\
\text { by residents }\end{array}$ & $\begin{array}{c}\text { Resident } \\
\text { applications at } \\
\text { national offices }\end{array}$ & $\begin{array}{c}\text { Non-resident } \\
\text { applications at } \\
\text { national offices }\end{array}$ \\
\hline $\begin{array}{l}\text { Post-accession } \\
\text { dummy }\end{array}$ & $0.12(0.12)$ & $-0.29(0.12)^{* *}$ & $-1.86(0.26)^{* * *}$ \\
\hline $\begin{array}{l}\text { Post-accession } \\
\text { trend }\end{array}$ & $0.05(0.01)^{* * *}$ & $0.05(0.02)^{* * *}$ & $-0.05(0.04)$ \\
\hline Pseudo R-squared & 0.844 & 0.895 & 0.924 \\
\hline
\end{tabular}

Predicting aggregate patent grants

Dependent variable: granted patents by filing quarter

\begin{tabular}{|c|c|c|c|c|c|}
\hline & $\begin{array}{c}\text { EPO grants to } \\
\text { residents of } \\
\text { accession } \\
\text { countries }\end{array}$ & $\begin{array}{c}\text { EPO grants to } \\
\text { residents } \\
\text { validated in } \\
\text { accession } \\
\text { countries }\end{array}$ & $\begin{array}{c}\text { Resident grants } \\
\text { at national } \\
\text { offices }\end{array}$ & $\begin{array}{c}\text { EPO grants to } \\
\text { non-residents } \\
\text { validated in } \\
\text { accession } \\
\text { countries }\end{array}$ & $\begin{array}{c}\text { Non-resident } \\
\text { grants at } \\
\text { national offices }\end{array}$ \\
\hline $\begin{array}{l}\text { Post-accession } \\
\text { dummy }\end{array}$ & $0.10(0.10)$ & $2.18(0.42)^{* * *}$ & $-0.12(0.07)$ & $2.01(0.19)^{* * *}$ & $-1.57(0.27)^{* * *}$ \\
\hline $\begin{array}{l}\text { Post-accession } \\
\text { trend }\end{array}$ & $0.07(0.01)^{* * *}$ & $-0.11(0.08)$ & $-0.02(0.02)$ & $0.03(0.09)$ & $-0.07(0.02)^{* * *}$ \\
\hline Number of observati & 1064 & 1064 & 912 & 1064 & 912 \\
\hline Number of countries & 14 & 14 & 12 & 14 & 12 \\
\hline Pseudo R-squared & 0.739 & 0.740 & 0.872 & 0.874 & 0.942 \\
\hline
\end{tabular}

All regressions include country and quarter-year dummies

Standard errors are robust and clustered on country.

Method of estimation is Poisson regression with robust standard errors 


\section{Figure D-1}

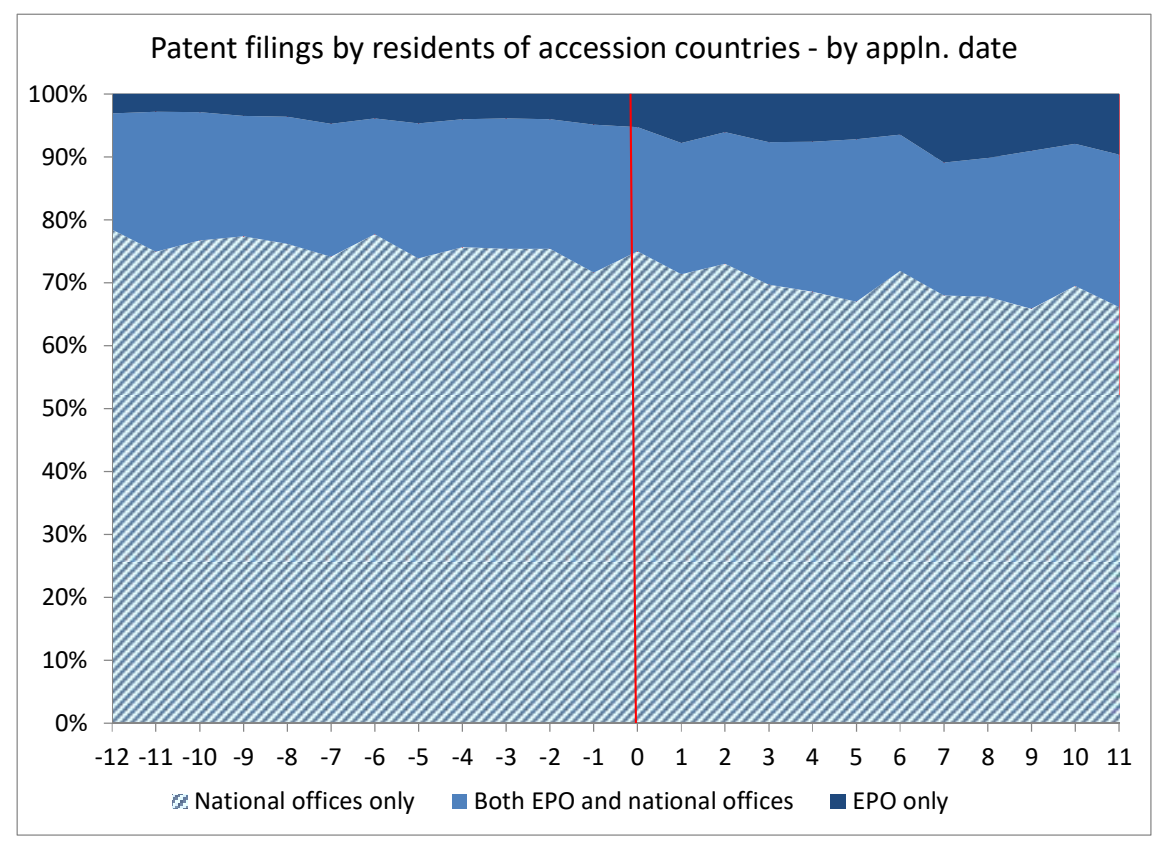

